\title{
1985 TECHNICAL COEFFICIENTS FOR INPUTS TO ENERGY TECHNOLOGIES
}

\author{
JOAN LUKACHINSKI AND RAYMOND G. TESSMER, JR.
}

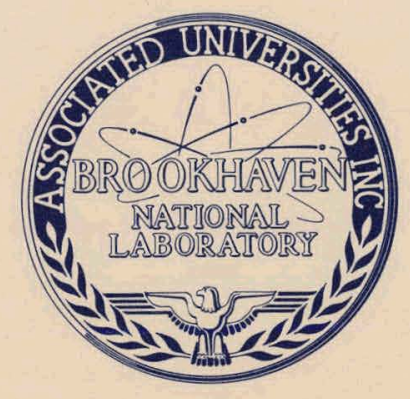

June 1976

ECONOMIC ANALYSIS DIVISION

NATIONAL CENTER FOR ANALYSIS OF ENERGY SYSTEMS

BROOKHAVEN NATIONAL LABORATORY ASSOCIATED UNIVERSITIES, INC. UNDER CONTRACT NO. E(30-1)-16 WITH THE UNITED STATES ENERGY RESEARCH AND DEVELOPMENT ADMINISTRATION 


\section{DISCLAIMER}

This report was prepared as an account of work sponsored by an agency of the United States Government. Neither the United States Government nor any agency Thereof, nor any of their employees, makes any warranty, express or implied, or assumes any legal liability or responsibility for the accuracy, completeness, or usefulness of any information, apparatus, product, or process disclosed, or represents that its use would not infringe privately owned rights. Reference herein to any specific commercial product, process, or service by trade name, trademark, manufacturer, or otherwise does not necessarily constitute or imply its endorsement, recommendation, or favoring by the United States Government or any agency thereof. The views and opinions of authors expressed herein do not necessarily state or reflect those of the United States Government or any agency thereof. 


\section{DISCLAIMER}

Portions of this document may be illegible in electronic image products. Images are produced from the best available original document. 
BNL 50532

[General, Miscellaneous, and Progress

Reports (Nonnuclear) - TID-4500]

\title{
1985 TECHNICAL COEFFICIENTS FOR INPUTS TO ENERGY TECHNOLOGIES
}

\author{
JOAN LUKACHINSKI AND RAYMOND G. TESSMER, JR.
}

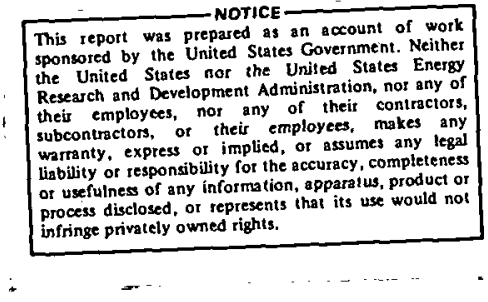

June 1976

Preparod for

ADMINISTRATOR FOR INTERNATIONAL AFFAIRS

UNITED STATES ENERGY RESEARCH AND DEVELOPMENT ADMINISTRATION

ECONOMIC ANALYSIS DIVISION

NATIONAL CENTER FOR ANALYSIS OF ENERGY SYSTEMS

BROOKHAVEN NATIONAL LABORATORY UPTON, NEW YORK 11973 
NOTICE

This report was prepared as an account of work sponsored by the United States Government. Neither the Unitcd States nor the United States Fnergy Research and Development Administration, nor any of their employees, nor any of their contractors, subcontractors, or their employees, miakes any wairianty, expreso or limplied, or 4 ssu!n! any legal liability or responsibility for the accuracy, completeness or usefulness of any information, apparatus, product or process disclused, or represcnts that its use would not infringe privately owned rights.

Printed in the United States of America

Available from

National Technical Information Service

U.S. Department of Commerce

5285 Port Royal Road

Springfield, VA 22161

Price: Printed Copy $\$ 4.00$; Microfiche $\$ 2.25$

July 1976

300 copies 


\section{ACKNOWLEDGEMENT}

This report is a revision of two earlier reports, "Technical Coefficients for Inputs to Energy Supply Sectors from Non-Energy Sectors". and "Technical Coefficients for Inputs to New Energy Technologies", by Mark Swift (January 1975 \& April 1975), initially issued by the center for Advanced Computation, University of Illinois at Urbana-Champaign, as CAC Technical Memoranda Nos. 46 \& 49 . This revision supercedes those reports and includes respecification of input-output coefficients for compatability with a 110 sector version of the combined energy optimization/input-output model developed jointly by CAC and BNL. 


\begin{abstract}
This report describes the incorporation of input-output technical coefficients tor five new energy supply and convcrcion technologies as estimated by Llie MITRE corporation into a 110 sector Energy I-0 Model. The five new technologies are solventrefining of coal, oil shale mining and retorting, high temperature gas-cooled reactor electriclty generation, high BTU coal gasification, and COGAS combined cycle electricity generation. Incorporation of seven existing energy supply and conversion technologies is also describer: crude oil and gas extrastion, coal mining, refined petroleum products, pipeline gas, fossil electric generation, and hydroelectric generation.

Non-energy input coefficients are given in units of 1967 $\$ 110^{5} \mathrm{BTU}$ and represent the inputs in constant 1967 dollars from non-energy sectors (e.g. manufacturing, transportation, services) required per $10^{6}$ BTU of energy production by each of these energy supply technologies. The 90 non-energy sectors included are based on the Bureau of Economic Analysis 83 sector input-output structure for 1967 with minor disaggregations. Energy input coefficients are given in units of $\mathrm{BTU} / \mathrm{BTU}$.
\end{abstract}


TABLE OF CONTENTS

Page

1. INTRODUCTION 1

2. COAL, CRUDE OIL \& GAS, REFINED 2

OIL PRODUCTS, AND PIPELINE GAS

3. FOSSIL ELECTRIC, LIGHT WATER REACTOR (LWR) 4

ELECTRIC, and HYDROELECTRIC

3.1 Disaggregating Petroleum and 9

Transportation Inputs

3.2 Process Vectors for Fossil 10

Electric and Electric Overhead 10

3. 3 Normalization 10

3.4 Adjustment of Process Coefficients 11

3.5 Reconciliation with BEA Electric 13

Utility sector Data

4. METHANE FROM COAL 13

4.1 Energy Supply Inputs 17

$\begin{array}{lll}4.2 & \text { Energy Protuct Inpiats } & 17\end{array}$

4. 3 Non-Energy Inpiats 17

5. SOLVENT-REFINED COAL 19

5.1 Energy Supply Inputs 19

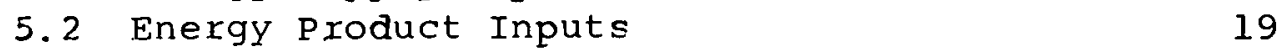

$\begin{array}{ll}5.3 \text { Non-Energy Inputs } & 19\end{array}$

6. SHALE OIL 19

6.1 Energy Supply Inputs 21

6.2 Energy product Inputs 21

6.3 Non-Energy Inputs 21 
Table of Contents (Con't)

Page

7. HIGH TEMPERATURE GAS-COOLED REACTOR (HTGR) ELECTRIC.

7.1 Electric Overhead and BEA 23 Resicual Allocation

7. 2 Energy Supply Inputs'

7.3 Energy Product Inputs

7.4 Non-Energy Inputs

8. COAL COMBINED CYCLE ELECTRIC 23

8.1 Energy Supply Inputs 25

8.2 Energy Product Inputs 25

8. 3 Non-Energy Inputs 25

$\begin{array}{ll}\text { REFE RENCES } & 27\end{array}$

APPENDIX: 1963-1957 Inflators 29 
Table 1

Table 2

Table 3

Table 4

Table 5

Table 6

Table 7

Table 8

Table 9

Table 10

Table 11

Table 12

Table 13
Alignment of BNL 110 with Other Classification Systems

1985 Coal Mining Coefficients

1985 Crude Oil \& Gas Extraction

6 Coefficients

1985 Refined Oil Products Coefficients

1985 Pipeline Gas Coefficients

1957 Non-Energy Process Coefficients for

12 Electricity

1967 Electric Operating Transactions and Residuals, and Residual Allocation

Coefficients

$14 \& 15$

1967 Fossil Electric. Iight water Reactor Electric, and Hydroelectric Coefficients Coefficients

1985 Solvent-Refined Coal Coefficients

1985 Shale Oil Coefficients

1985 High Temperature Gas-Cooled Reactor Coefficients 


\section{INTRODUCTION}

This memorandum describes the incorporation of inputoutput coefficients for the following new energy supply technologies into a 110 sector input-output model of the nation's economy:

1. Solvent-Refined Coal (SRC)

2. Shale Oil

3. High Temperature Gas-Cooled Reactor (HTGR)

4. Coal Combined Cycle Electricity Generation (CCC)

5. High BTU Coal Gasification (Methane from Coal)

These coefficients enable expansion of energy detail in an input-output morel which was jointly developed by the University of Illinois and Brookhaven National Laboratory. Technical descriptions of the basic model are presented by $C . W$. Bullard in (1) and by D. J. Behling et al, in [2].

Besides the five new supply technologies listed above, the morel includes the following seven existing energy supply sectors: coal, crude oil and gas, refined oil products, pipeline gas, fossil generater electricity, electricity generated by light water reactors, and hydroelectricity. Incorporation of I-0 coefficients for these technologies is also described in the report.

There are three distinct types of inputs which are used in the model referenced above: energy supply, energy product, and nonenergy. Energy supplies consist of energy resources, processed energy fuels and electricity. By definition, energy supply sectors distribute their output to only energy supply and/or energy product sectors. The flows of energy supplies from one sector to another include estimates of any losses involved in conversion and transmission. The output of these energy supply sectors are measured in British Thermal Units (BTU) per year.

Energy products are non-substitutable, end-use forms of energy. The model defines eight distinct energy products: coke (or ore reduction feedstocks), chemical feedstocks, motive power, process heat, water heat, space heat, air conditioning, and electric power. All energy inputs to a sector for final use by that sector and not for conversion to some other energy form are expressed in terms of energy products. That is, the energy products reflect the non-substitutable end-use demands for energy. For example, an oil refinery could use either oil or gas to meet its space heating neers, but 1t could not úse motive power to do so. It's reruirements for heating of office and manufacturing space is thus specified as a demand tor space heat, not as a demarid for either the oil or gas used to meet the demand. Output of energy 
product sectors is also measured in BTU per year.

When calculating outputs of the energy product sectors, certain assumptions were made in the previous version of the I-0 model to exclude counting "free" by-products, such as waste heat from the energy supply sectors. In the current version of the I-0 moiel, waste heat from total energy systems is includer in calculating the outputs of the space heat and air conditioning sectors. The new definition for space heat has also been made consistent with ERDA-48 [17], by dividing the space heat coefficients by 1.58 .

There are 90 non-energy sectors consisting of a straightforward, partial disaggregation of 78 sectors in the inputoutput structure of the Bureau of Economic Analysis (BEA) [3]. Output of these sectors is measured in 1967 constant oollars. Table I lists the twelve energy supply sectors, the eight energy product sectors and the 90 non-energy sectors and also indicates the correspondence between these sectors and the BEA classification.

The primary data source for the new energy technology coefficients presented in this paper is a report by the MITRE corporation [6]. The report gives detailed cata on input requirements from the non-energy sectors and on the BTUs reruired from energy supply sectors. However, it gives almost no information on energy product reruirements. The fuel needed for some motive power renuirements is includer and one process fuel renuirement is identified as process heat, but no mention is made of such reruirements as space heat, water heat, or lighting. These must be estimater from similar technology sector reruirements as הeriver by Knecht [16].

\section{CONL, CRUDE ULL \& GAS, KEFINED OIL FRODUCTS and PIFẼLINE GAS}

These four input-output sectors represent existing energy supply technologies which correspond, on a one-to-one basis, to sectors 7.00, 8.00, 31.01 and 68.02 as defined by the Bureau of Economic Analysis (BEA) in [3]. The non-energy input coefficients

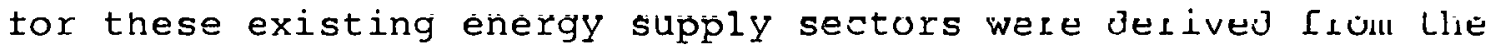
Bureau of Labor Statistics 1985 134-order input-output forecast [15]. The 1935 134-order transactions natrix was inflated from 1953 \$ to 1967 s ueing the BLS supplied deflators, and then the 1.29-order transactions were aggregated to the 110-order BNL classification. Each of the resulting transactions elements was then divided by the corresponiing 1967 domestic outpat in terms of BTUs (from [16]) to obtain coefficients in units of 1967 per $10^{6}$ BTU of energy output. 
Table 1. Sectoral Classification of Energy Input-Output Model and Alignment with Other Classification Systems

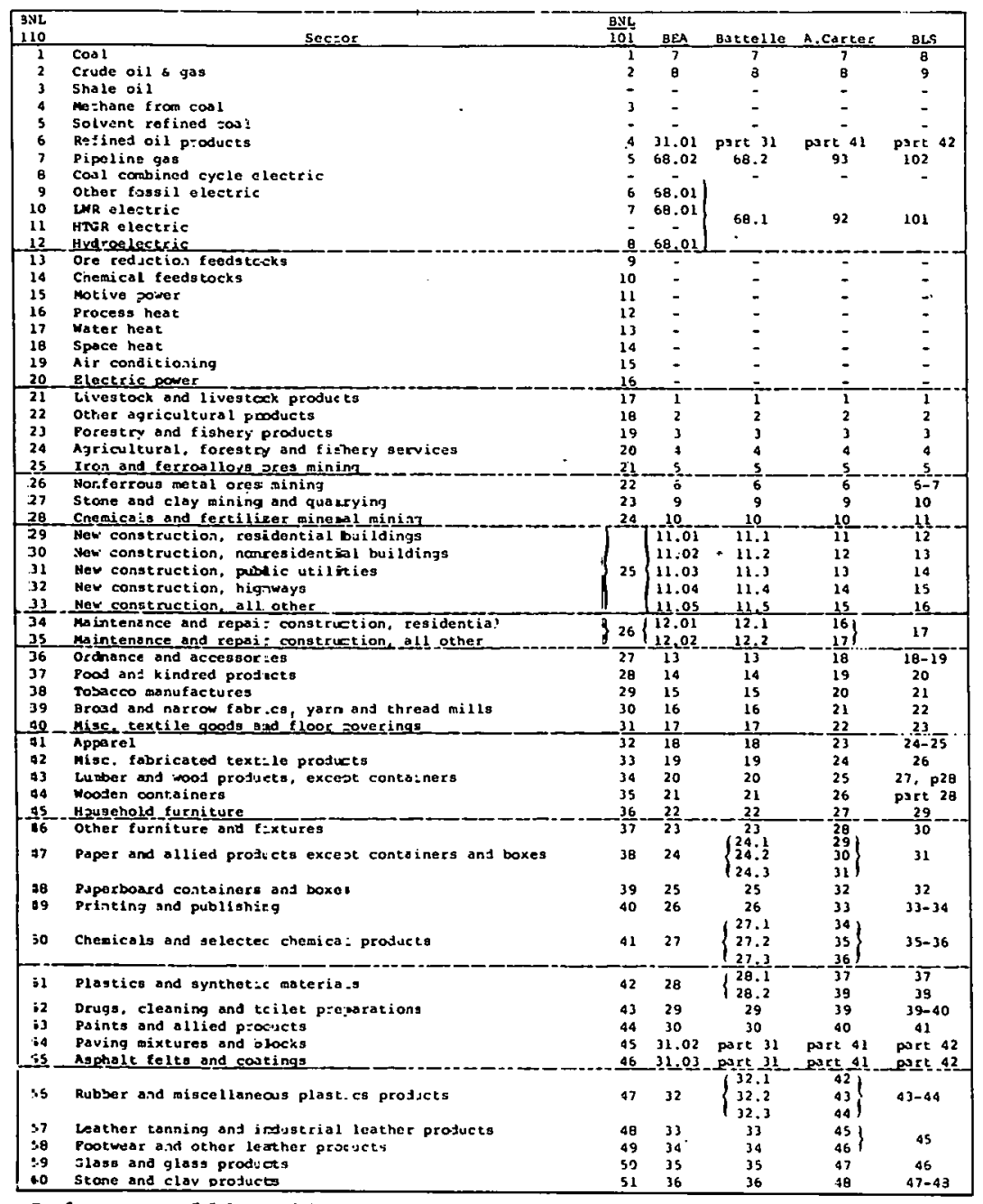

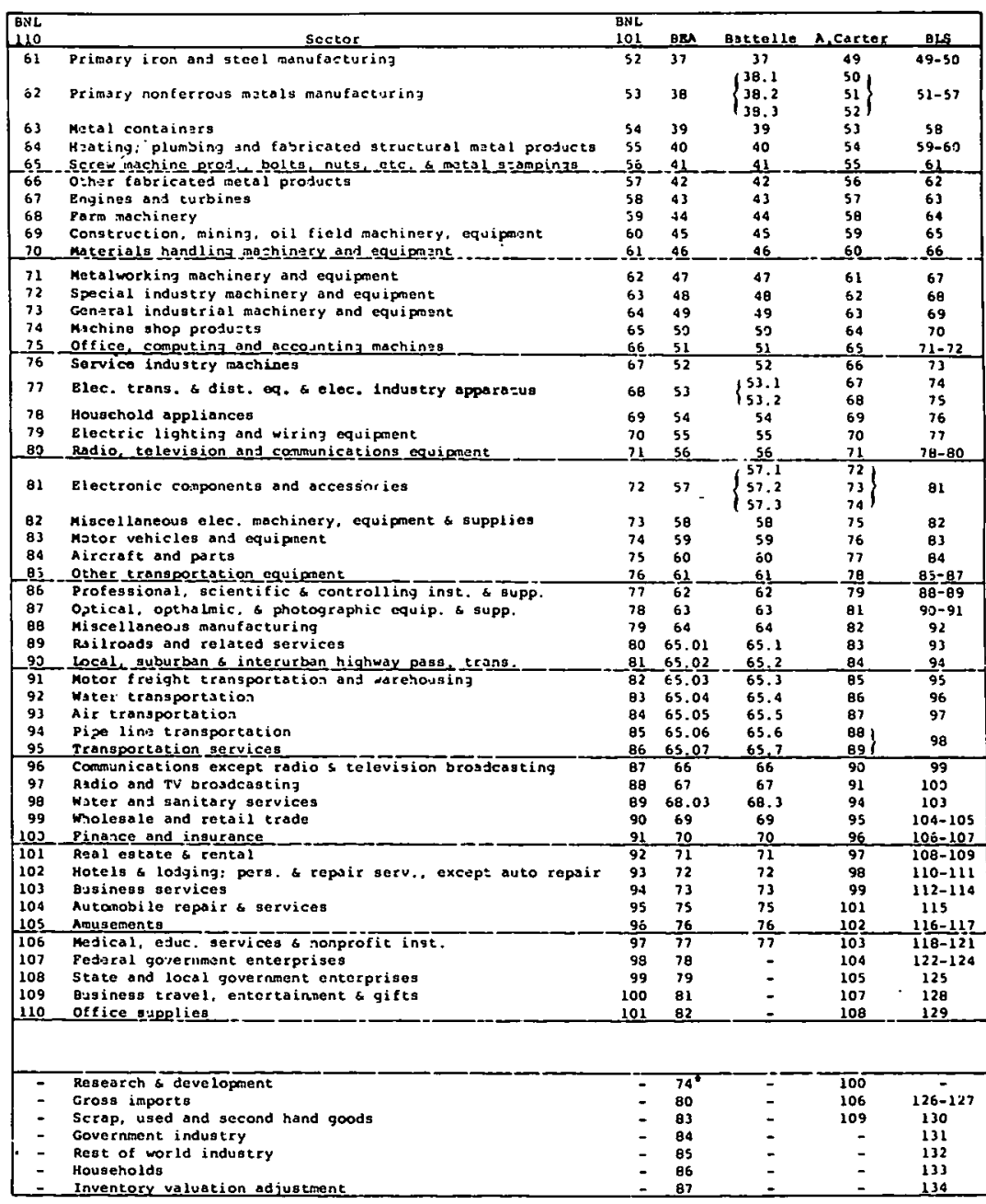

Code BNL 110 - 110 sector version

BNL 101 - 101 sector version

BEA - Bureau of Economic Analysis, U.S. Dept. of Commerce

Battelle- Classification used in reference (7).

A.Carter- Professor Ann Carter, Brandeis University

BLS - Bureau of Labor Statistics, U.S. Dept. of Labor 
Historical energy supply and energy product input coefficients for these sectors were rerived at the University of Illinois for the year 1967 [16]. The energy product coefficients have been projecter to 1985 by using certain projections for floor space, saturation, etc., contained in the "Energy Sourcebook". [18] Energy supply coefficients are not projected because they are endogenously retermined by solving the combined I-O/LP model. The resulting $A-$ matrix coefficients of production are presented in Tables 2-5.

\section{FOSSIL ELECTRIC, LIGHT WATER REACTOR (LWR) ELECTRIC,} and HYDROELECTRIC

The present model equates Nuclear Electricity with the Light Water Reactor (LWR) and Renewable Electricity with hydroelectric generation. James Just [6] yives a cuilent 1974 vector for the LWR. Rudyard Istvan [13] lists 1953 vectors for fossil steam, other fossil, nuclear, and hydroelectric generation. He also gives vectors for transmission, distribution, and a iministratiun $1 \in=$ quirements. In addition, there exists the total transactions vector For inputs to electric utilities (from BEA [14]) which represents a set of 1967 control totals for all rerulrements of the electric utilities sector.

The Istvan vectors are listed in 1963 \$ transactions and have single, aggregated sectors for transportion (where BEA has seven separate sectors), and for petroleum products (where BEA has three separate sectors (number 6 corresponding to refined oil products; number 54, corresponding to asphalt paving; and number 55, corresponiing to asphalt roofing and siding)). Converting Istvan's and Just's data to a form usable for our purposes thus involves five steps:

- Disaggregating Istvan's transactions data for transportation and petroleum

- Aggregating Istvan's process vectors to get transactions data for fossil electric (fossil steam \& other fossil), hydroelectric, and electric overhead (distribution \& transmission \& administration).

- Normalizing the disaggregated transactions vectors with respect to domestic electricity generation 1 n 1963 to get $I-0$ coefficients in terms of 1963 \$ $/ 10^{5} \mathrm{BTU}$; and multiplying these coefficients by inflators to convert them to 1967 $\$ / 10^{\mathrm{i}}$ BTU.

- Comparing Istvan's fossil electric and hydroelectric coefficients with Just's LWR coefficients, and adjusting for comparability.

- Converting thcse $1967 \$ 10^{6}$ BTU process coefficients to 
TABLE 2

1985 COAL MINING COEFFICIENTS

\begin{tabular}{|c|c|c|c|c|c|c|}
\hline $\begin{array}{l}\text { BNL } \\
\underline{1} 10\end{array}$ & $\begin{array}{l}\text { A MATRI) } \\
\text { COEFFIC }\end{array}$ & & $\begin{array}{l}\text { BNL } \\
110\end{array}$ & \multicolumn{3}{|c|}{$\begin{array}{l}\text { A MATRIX } \\
\text { COEFFICIENTS }\end{array}$} \\
\hline 1 & 0 & BTU /BTU & 56 & .002392 & $1967 \$ / 10^{6}$ & BTU \\
\hline 2 & 0 & & 57 & 0 & & \\
\hline 3 & 0 & & 58 & 0 & & \\
\hline 4 & 0 & & 59 & 0 & & \\
\hline 5 & 0 & & 60 & .000141 & & \\
\hline 6 & 0 & & 61 & .004562 & & \\
\hline 7 & 0 & & 62 & .000006 & & \\
\hline 8 & 0 & & 63 & 0 & & \\
\hline 9 & 0 & & 64 & 0 & & \\
\hline 10 & 0 & & 65 & 0 & & \\
\hline 11 & 0 & & 66 & .001157 & & \\
\hline 12 & 0 & & 67 & .004883 & & \\
\hline 13 & 0 & & 68 & 0 & & \\
\hline 14 & .000004 & & 69 & .008829 & & \\
\hline 15 & .000079 & & 70 & .000070 & & \\
\hline 16 & .000527 & & 71 & .000460 & & \\
\hline 17 & .000006 & & 72 & 0 & & \\
\hline 18 & 0 & & 73 & .000231 & & \\
\hline 19 & 0 & & 74 & .001213 & & \\
\hline 20 & .000133 & $V$ & 75 & 0 & . & \\
\hline 21 & 0 & $1967 \$ / 106$ BTU & 76 & 0 & & \\
\hline 22 & 0 & & 77 & .000665 & & \\
\hline 23 & 0 & & 78 & 0 & & \\
\hline 24 & 0 & & 79 & .001294 & & \\
\hline 25 & .000004 & & 80 & 0 & & \\
\hline 26 & .000017 & & 81 & 0 & & \\
\hline 27 & .000062 & & 82 & .000083 & & \\
\hline 28 & .000004 & & 83 & .000113 & & \\
\hline 29 & 0 & & 84 & 0 & & \\
\hline 30 & 0 & & 85 & .000564 & & \\
\hline 31 & 0 & & 86 & 0 & & \\
\hline 32 & 0 & & 87 & 0 & & \\
\hline 33 & 0 & & 88 & 0 & & \\
\hline 34 & 0 & & 89 & .001275 & & \\
\hline 35 & .000450 & & 90 & 0 & & \\
\hline 36 & 0 & & 91 & .001014 & & \\
\hline 37 & 0 & & 92 & .000044 & & \\
\hline 38 & 0 & & 93 & .000126 & & \\
\hline 39 & 0 & & 94 & .000010 & & \\
\hline 40 & 0 & & 95 & .000014 & & \\
\hline 41 & 0 & & 96 & .000577 & & \\
\hline 42 & 0 & & 97 & 0 & & \\
\hline 43 & .001340 & & 98 & .000139 & & \\
\hline 44 & 0 & & 99 & .005403 & & \\
\hline 45 & 0 & & 100 & .002861 & & \\
\hline 46 & 0 & & 101 & .005127 & & \\
\hline 47 & .000092 & & 102 & 0 & & \\
\hline 48 & 0 & & 103 & .004776 & & \\
\hline 49 & .000004 & & 104 & .000783 & & \\
\hline so & .003357 & & 105 & 0 & & \\
\hline 51 & 0 & & 106 & ל & & \\
\hline 52 & 0 & & 107 & .000166 & & \\
\hline 53 & 0 & & 108 & .000042 & & \\
\hline 54 & .000079 & & 109 & .000939 & $\sqrt{1 / 2}$ & \\
\hline 55 & .000029 & $V$ & 110 & .000049 & $\sqrt{7}$ & \\
\hline
\end{tabular}


TABLE 3

1985 CRUDE OIL AND GAS EXTRACTION COEFFICIENTS

\begin{tabular}{|c|c|c|c|c|c|}
\hline $\begin{array}{l}\text { BNL } \\
110\end{array}$ & $\begin{array}{l}\text { A MATRIX } \\
\text { COEFFICIENTS }\end{array}$ & & $\begin{array}{l}\text { BNL } \\
110 \\
\end{array}$ & $\begin{array}{l}\text { A MATRIY } \\
\text { COEFFIC }\end{array}$ & \\
\hline 1 & 0 & $\mathrm{BTU} / \mathrm{BTU}$ & 56 & .000599 & $1967 \$ / 10^{6} \mathrm{~B}$ \\
\hline 2 & .024703 & & 57 & 0 & \\
\hline 3 & 0 & & 58 & 0 & \\
\hline 4 & 0 & & 59 & 0 & \\
\hline 5 & 0 & & 60 & .001169 & \\
\hline 6 & 0 & & 61 & .002112 & \\
\hline 7 & 0 & & 62 & 0 & \\
\hline 8 & 0 & & 63 & 0 & \\
\hline 9 & 0 & & 64 & .001858 & \\
\hline 10 & 0 & & 65 & $u$ & \\
\hline 11 & 0 & & 66 & .000751 & \\
\hline 12 & 0 & & 67 & .001308 & \\
\hline 13 & 0 & & 68 & 0 & \\
\hline 14 & .000003 & & 69 & .001555 & \\
\hline 15 & .000059 & & 70 & 0 & \\
\hline 16 & .011095 & & 71 & 0 & \\
\hline 17 & .000004 & & 72 & 0 & \\
\hline 18 & 0 & & 73 & .001670 & \\
\hline 19 & 0 & & 74 & .000027 & \\
\hline 20 & .000799 & $\sqrt{n}$ & 75 & u & \\
\hline 21 & 0 & $\overline{1967 \$ / 10^{6} \mathrm{BTU}}$ & 76 & 0 & \\
\hline 22 & 0 & & 77 & . Oก44R5 & \\
\hline 23 & 0 & & 78 & 0 & \\
\hline 24 & 0 & & 79 & .000020 & \\
\hline 25 & 0 & & 80 & .000247 & \\
\hline 26 & .000006 & & 81 & .001938 & \\
\hline 27 & 0 & & 82 & .000052 & \\
\hline 28 & 0 & & 83 & .000027 & \\
\hline 29 & 0 & & 84 & 0 & \\
\hline 30 & 0 & & 85 & 0 & \\
\hline 31 & 0 & & 86 & .000243 & \\
\hline 32 & 0 & & 87 & 0 & \\
\hline 33 & 0 & & 88 & 11 & \\
\hline 34 & 0 & & 89 & .002074 & \\
\hline 35 & .007193 & & 90 & 0 & \\
\hline 36 & 0 & & 91 & .001649 & \\
\hline 37 & 0 & & 92 & .000073 & \\
\hline 38 & 0 & & 93 & .000205 & \\
\hline 39 & 0 & & 94 & .000017 & \\
\hline 40 & .000146 & & 95 & .000024 & \\
\hline 41 & 0 & & 96 & .000939 & \\
\hline 42 & 0 & & 97 & 0 & \\
\hline 43 & .000003 & & 98 & .000226 & \\
\hline 44 & 0 & & 99 & .008787 & \\
\hline 45 & 0 & & 100 & .004652 & \\
\hline 46 & 0 & & 101 & .008338 & \\
\hline 47 & .000093 & & 102 & 0 & \\
\hline 48 & 0 & & 1,03 & .007767 & \\
\hline 49 & .000024 & & 104 & .001273 & \\
\hline 50 & .005400 & & 105 & 0 & \\
\hline 51 & 0 & & 106 & .000285 & \\
\hline 52 & 0 & & 107 & .000271 & \\
\hline 53 & .000240 & & 108 & .000069 & \\
\hline 54 & .000132 & & 109 & .001527 & \\
\hline 55 & .000048 & & 110 & .000080 & \\
\hline
\end{tabular}


TABLE 4

1985 RFFT TED OIL PRODUCTS COEFFICIENTS

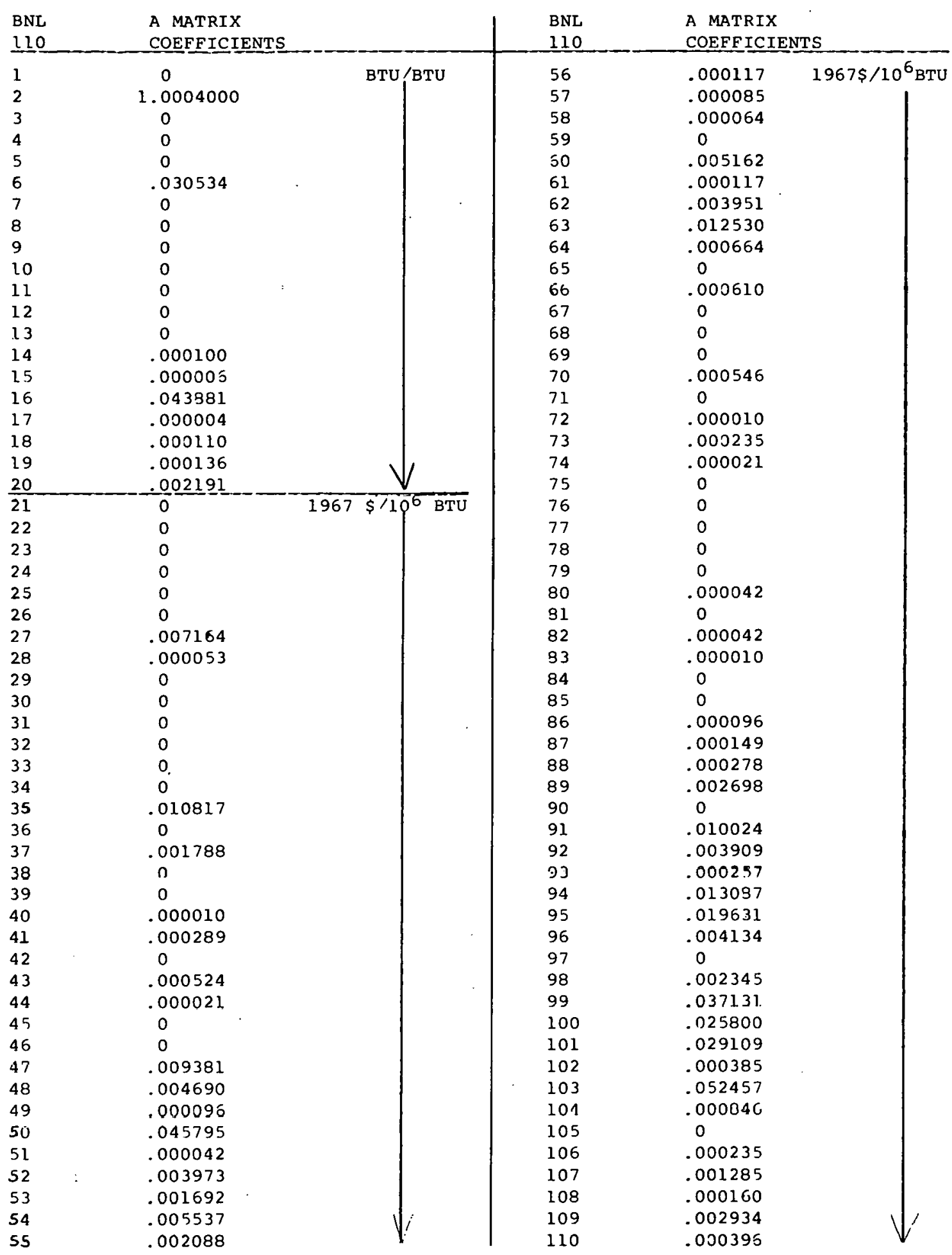


TABLE 5

1985 PIPELINE GAS COEFFICIENTS

\begin{tabular}{|c|c|c|c|c|c|c|}
\hline $\begin{array}{l}\text { BNL } \\
110\end{array}$ & $\begin{array}{l}\text { A MATRIX } \\
\text { COEFFIC }\end{array}$ & & $\begin{array}{l}\text { BNL } \\
110 \\
\end{array}$ & $\begin{array}{l}\text { A MATRIX } \\
\text { COEFFICI }\end{array}$ & & \\
\hline 1 & 0 & $\mathrm{BTU} / \mathrm{BTU}$ & 56 & .000093 & 1967 & $\$ 110^{6} \mathrm{BTU}$ \\
\hline 2 & .979534 & & 57 & 0 & & \\
\hline 3 & 0 & & 58 & 0 & & \\
\hline 4 & 0 & & 59 & 0 & & \\
\hline 5 & 0 & & 50 & 0 & & \\
\hline 6 & 0 & & 61 & 0 & & \\
\hline 7 & .032490 & & 62 & 0 & & \\
\hline 8 & 0 & & 63 & 0 & & \\
\hline 9 & 0 & & 04 & 0 & & \\
\hline 10 & 0 & & 65 & 0 & & \\
\hline 11 & 0 & & 66 & 0 & & \\
\hline 12 & 0 & & 67 & 0 & & \\
\hline 13 & 0 & & 68 & 0 & & \\
\hline 14 & .000004 & & 69 & 0 & & \\
\hline 15 & .000072 & & 70 & 0 & & \\
\hline 16 & 0 & & 71 & 0 & & \\
\hline 17 & .000028 & & 72 & 0 & & \\
\hline 18 & .000467 & & 73 & 0 & & \\
\hline 19 & .000076 & & 74 & .000023 & & \\
\hline$\underline{20}$ & .000224 & $y$ & 75 & 0 & & \\
\hline 21 & 0 & $1967 \$ 110^{6} \mathrm{BTU}$ & 76 & 0 & & \\
\hline 22 & 0 & & 77 & 0 & & \\
\hline 23 & 0 & & 78 & 0 & & \\
\hline 24 & 0 & & 79 & .000007 & & \\
\hline 25 & 0 & & 80 & 0 & & \\
\hline 26 & 0 & & 31 & 0 & & \\
\hline 27 & 0 & & 82 & .000046 & & \\
\hline 28 & 0 & & 33 & .000007 & & \\
\hline 29 & 0 & & 84 & 0 & & \\
\hline 30 & 0 & & 85 & 0 & & \\
\hline 31. & $n$ & & 36 & 0 & & \\
\hline 32 & 0 & & 07 & 0 & & \\
\hline 33 & 0 & & RB & 0 & & \\
\hline 34 & 0 & & 89 & .000156 & & \\
\hline 35 & .008602 & & 90 & 0 & & \\
\hline 36 & 0 & & 91 & .001290 & & \\
\hline 37 & 0 & & 92 & .000602 & & \\
\hline 38 & 0 & & 93 & .000015 & & \\
\hline 39 & 0 & & 94 & .002776 & & \\
\hline 40 & 0 & & 95 & .004160 & & \\
\hline 11 & nกn1:56 & - & 96 & .005481 & & \\
\hline 42 & 0 & & 97 & 0 & & \\
\hline 43 & 0 & & 98 & .000250 & & \\
\hline 44 & 0 & & 99 & .005481 & & \\
\hline 15 & $n$ & & 100 & .009947 & & \\
\hline 46 & 0 & & 101 & .007840 & & \\
\hline 47 & .000555 & & 102 & 0 & & \\
\hline 48 & 0 & & 103 & .033876 & & \\
\hline 49 & .000054 & & 104 & .001610 & & \\
\hline 50 & .000031 & & 105 & 0 & & \\
\hline 51. & 0 & & 106 & .000328 & & \\
\hline 52 & 0 & & 107 & .003605 & & \\
\hline 53 & 0 & & 108 & .021974 & & \\
\hline 54 & .000156 & $V$ & 109 & .005614 & & 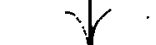 \\
\hline 55 & .000054 & Y. & 110 & .000336 & & \\
\hline
\end{tabular}


transactions; adjusting these transactions to account for the actual 1967 figures given by $B E A$; and recomputing final coefficients for fossil, LWR, and hydroelectric I-0 sectors.

3.1 Disaggregating petroleum and Transportation Inputs

To disaggregate petroleum and transportation we will use the 1967 transactions data for inputs to the electric utilities sector which is available from BEA [14] and assume that all of Istvan's process vectors (Table 3-1 in [13]) use these inputs in the same proportions as they are used by the electric utilities sector as a whole. We note that the three petroleum sectors are $31.01,31.02$, and 31.03 in the BEA classification and the seven transportation sectors are 65.01, 65:02, 65.03, 65.04, 65.05, 65.06, and 65.07, while the electric utilities sector is 68.01. Letting $\mathrm{TT}_{i} \mathrm{j}_{\mathrm{f}}$ indicate the 1963 transactions, as given by BEA, for inputs from sector $i$ to sector $j$, we can calculate, on the basis of the assumption above, the following fractions for disaggregating Istvan's sectors 31 and 65 :

$\mathrm{F}_{31.01}=\frac{\mathrm{TT}_{31.01}, 68.01}{+\mathrm{TT}_{31.02,68.01}+\mathrm{TT}_{31.03,68.01}}=1.0$

$\mathrm{F}_{31.02}=\frac{\mathrm{TT}_{31} .02,68.01}{\mathrm{TT}_{31.01,68.01}+\mathrm{TT}_{31.02,68.01}+\mathrm{TT}_{31.03,68.01}}=0.0$

$\mathrm{F}_{31.03}=\frac{\mathrm{TT}_{31.03}, 68.01}{\mathrm{TT}_{31.01,68.01}+\mathrm{TT}_{31.02,68.01}+\mathrm{TT}_{31.03,68.01}}=0.0$

$\mathrm{F}_{65.01}=\frac{{ }^{\prime \prime 1} 65.01,68.01}{\mathrm{TT}_{65.01,68.01}+\mathrm{TT}_{65.02,68.01}+\ldots+\mathrm{TT}_{65.07,68.01}}$

and so on, resulting in the following remaining fractions:

$$
\begin{aligned}
& F_{65.02}=0.0 \\
& F_{65.03}=0.19522
\end{aligned}
$$




$$
\begin{aligned}
& F_{65.04}=0.09213 \\
& F_{65.05}=0.00062 \\
& F_{65.06}=0.00231 \\
& F_{65.07}=0.0
\end{aligned}
$$

Since $\mathrm{TT}_{31.02,68.01}$ and $\mathrm{TT}_{31.03,68.01}$ are both zero for 1963 and 1967 we end up simply allotting all of the transaction given by Istvan for sector 31 to sector 31.01 .

Letting ISTVAN $_{i, j}$ represent the six electric transactions vectors taken from Istvan's work, anc ELTT $i, j$ the corresponding disaggregater transaclions, we gct:

$$
\begin{aligned}
& \operatorname{ELTT}_{31.01, j}=F_{31.01} * \operatorname{ISTVAN}_{31, j}=\operatorname{ISTVAN}_{31, j} \\
& \operatorname{ELTT}_{31.02, j}=F_{31.02} * \operatorname{ISTVAN}_{31, j}=0 \\
& \operatorname{ELTT}_{31.03, j}=F_{31.03} * \operatorname{ISTVAN}_{31, j}=0 \\
& \operatorname{ELTT}_{65.01, j}=F_{65.01} * \operatorname{ISTVAN}_{65, j}=.70972 * \operatorname{ISTVAN}_{65, j} \\
& \cdot \\
& . \\
& \operatorname{ELTT}_{65.07, j}=F_{65.07}{ }^{-} \operatorname{ISTVAN}_{6.5, j}=0.0
\end{aligned}
$$

3.2 Process Vectors for Fossil Electric and Electric Overhead

We now add the vector for Other Fossil $(j=3)$ to the vector for Fossil steam $(j=1)$ Lo get a total fossil fuel electric qeneration vector. Further, lhe vectury for tronaminion $(j=4)$, Distribution $(j=5)$, and Administration $(j=6)$ are added to obtain an electric overhear transactions vector.

3.3 Normalization

We now have a three column matrix of 1963 dollar inpits to electricity production. The columns are: (1) Fossil fuel electricity generation, (2) Hydroelcctric generation, and (3) Electric overhead. To get the corresponding coefficients we normalize the elements of these columns by the appropriate domestic generation of electricity in 1963 for each column, expressed in $10^{6}$ BTUs. The electric overhead requirements are assumed to apply to all electricity regardless of how it was generated and so are normalized by total domestic production of electric utilities for 1.963. The figures for electric generation in 1953 are taken from the 1971 Statistical Yearbook of the Edison Electric Institute [8]: 
EGEN63 $_{1}=$ Total Fossil Generation $=2.5523 \times 10^{9} \mathrm{BTU}$

EGEN632 32 Hycroelectric Generation $=.56572 \times 10^{9} \mathrm{BTU}$

EGEN633 $=$ Total Domestic Generation $=3.1290 \times 10^{9} \mathrm{BTU}$

Letting ELAA63i,j denote the coefficients for inputs to the electric generation vectors in $1963 \$ / 10^{6}$ BTU we can write the calculations as follows:

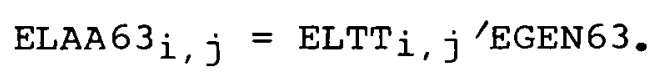

To convert these coefficients to $1967 \$ / 10^{6}$ BTU we assume that the physical requirements maintained the same proportions to gross romestic outpiats between 1963 and 1957 (equivalent to assuming constant technologies or proruction functions) and adjust the coefficients only on the basis of changes in relative prices. A vector of price inflators for 1963 to 1967, MU6367i, is deriver in the Appendix. Letting ELAA67 $i, j$ denote the 1967 input coefficients we perform the following operation:

$$
\operatorname{ELAA67} \mathbf{i}, j=\operatorname{ELAA63} \mathbf{i}, \mathbf{j} \star_{\text {MU6367 }} \mathbf{i}
$$

This assumes that the same changes in relative prices are experienced by all purchasing sectors.

We now have a matrix of input coefficients to electricity production in terms of $2967 \$ / 10^{6} \mathrm{BTU}$ which has three columns. By inserting the MITRE vector for the LWR into the second column and moving columns two and three to the right, we get a four column matrix whose columns are: (1) Fossil electric, (2) LWR or Nuclear Electric, (3) Hydroelectric, and (4) Electric overhead.

3.4 Adjustment of Process Coefficients

Inspection of process coefficients for fossil electric, LWR electric and hydroelectric reveals inconsistencies between the Istvan and the Just data. These inconsistencies were resolved in three ways. For sectoral requirements identified by Istvan and not by Just, the fossil electric coefficient specified by Istvan was inserted into the LWR vector of coefficients. For sectoral reruilements identitien by Just and not by Istvan, the LWR coefficient was inserter into the fossil and hydroelectric vectors. Finally, arjustments were mare to sectors in which fossil and LWR coefficients were clearly out of line with each other. Fossil versus nuclear coefficient ratios from Istvan, Table 3.5, were used as control ratios for this purpose. The resulting process coefficients for fossil electric, LWR electric, lyourvelectric, and electric overhear are presented in Table 6. Coefficients which were arjusted to obtain compsabilily of vectors are so icentified, and energy input coefficients are not listed because they have been obtained from another source. 
TABLE 6

1967 NON-ENERGY PROCESS COEFFICIENTS FOR ELECIIRICITY

(1967 $\left.\$ / 10^{6} \mathrm{BTU}\right)$

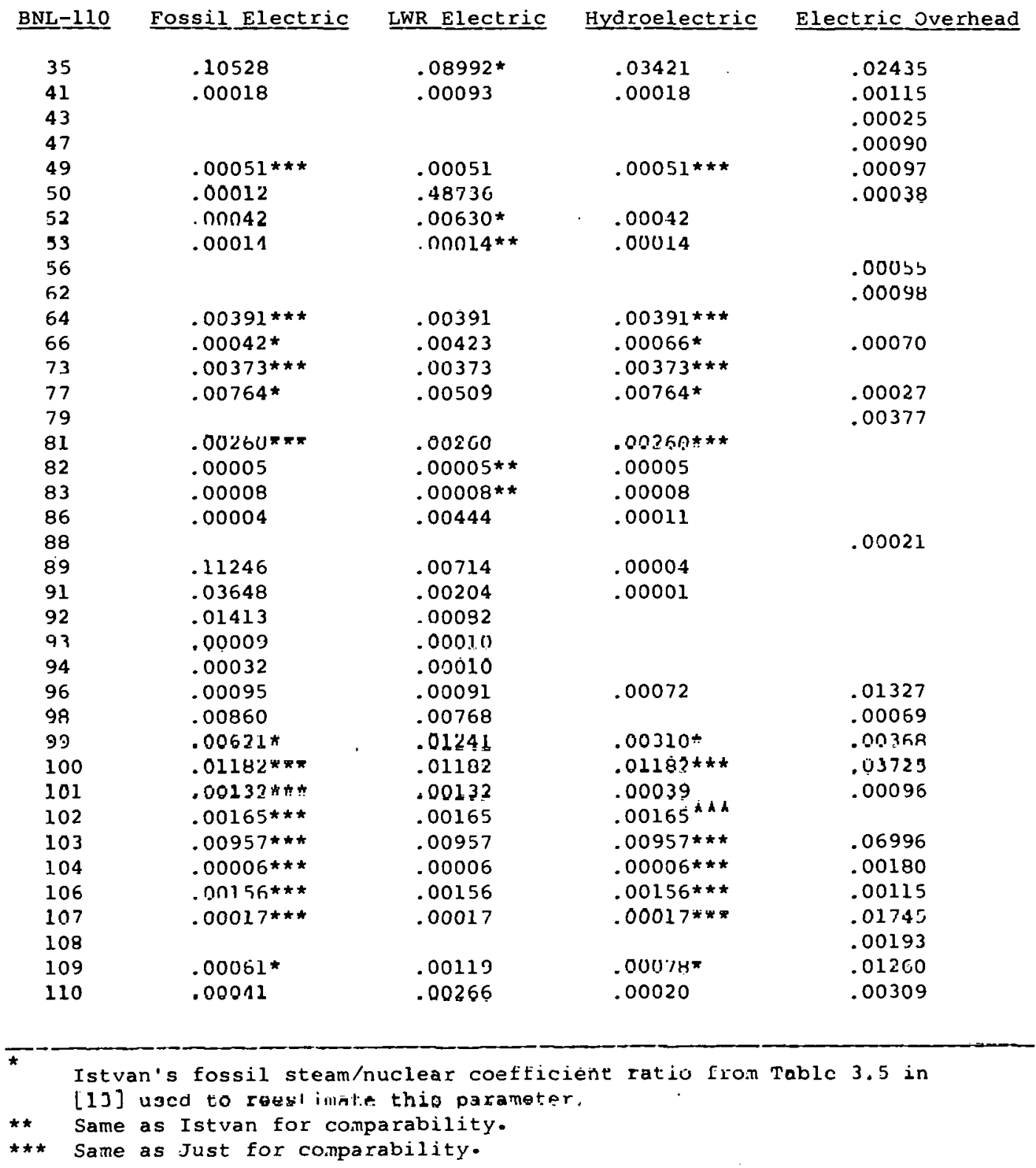


3.5 Reconciliation with BEA Electric Utility Sector Data

We now have electric operating coefficients for each of three generating technologies: fossil-fueled, nuclear, and hydroelectric, and for overhead. Since these coefficients have been derived from independent sturies, they will not generally be consistent with the figures from BEA for total reruirements by the electric utility incustry for 1967. To ensure consistency of our energy supply sector input transactions with those of other sectors in the model which are taken from the BEA data, we must control the transactions implied by our four electric coefficient vectors to those given by BEA for the electric utility industry.

The first step is to add the overhead coefficients to each of the three electric generation vectors. This gives total operating remirements per BTU of output for the three types of electricity generation. These coefficients are then converted to 1967 dollar transactions. They are multiplied by historical 1967 production of electricity for each process. Electric utility generation for 1967, taken from [8] and multiplied by the conversion factor, 3412.8 BTU/kw-hr., gives the following levels of production:

$$
\begin{aligned}
& \text { Fossil electric }-3.362 \times 10^{15} \mathrm{BTU} \\
& \text { LWR electric - } .026 \times 10^{15} \mathrm{BTU} \\
& \text { Hydroelectric - } .756 \times 10^{15} \mathrm{BTU} \\
& \text { Total electric - } 4.144 \times 10^{15} \text { BTU. }
\end{aligned}
$$

Transactions for the three processes based on Just and Istvan data is presented in Table 7, and their total (Estimate Total) is compared with 1967 BEA transaction data (BEA Total) for sector 68.01, Electric Utilities. For sectors in which BEA Total is greater than the Estimate Total, the difference is listed in the Residual column. These sectoral residuals are allocated to the three prosesses in the following way. They are first divided by total 1967 output of electricity, giving coefficients with units of $1967 \$ / 10^{6} \mathrm{BTU}$. These coefficients are then added to the total operating requirement coefficient vector for fossil, LWR, and hydroelectric. These are the final I-0 coefficients to be used in our I-0 morel, and they are listed in Table 8.

Input coefficients for energy product sectors are taken from [16] and projected by BNL to 1985. Input coefficients for energy supply sectors are taken directly fron [16], but not projected to 1985 because they are endogenously determined in an I-0/LP model solution.

\section{METHANE FROM COAL}

Lignite is used to produce a pipeline-quality gas which can substitute for natural gas. The technology examined in the 
TABLE 7

1967 ELECTRIC OPERATING TRANSACTIONS AND RESIDUALS (1967 Dollars)

AND RESIDUAL ALLOCATION COEFFICIENTS (1967\$/10 BTU)

\begin{tabular}{|c|c|c|c|c|c|c|c|}
\hline $\begin{array}{l}\text { BNL } \\
110 \\
\end{array}$ & $\begin{array}{c}\text { Fossil } \\
\text { Electric }\end{array}$ & $\begin{array}{l}\text { Nuclear } \\
\text { LWR } \\
\text { Electric }\end{array}$ & $\begin{array}{l}\text { Hydro- } \\
\text { Electric }\end{array}$ & $\begin{array}{c}\text { Estimate } \\
\text { Total }\end{array}$ & $\begin{array}{c}\text { BEA } \\
\text { Total }\end{array}$ & Residual & $\begin{array}{l}\text { Residual } \\
\text { Allocation } \\
\text { Coefficient }\end{array}$ \\
\hline \multicolumn{8}{|l|}{$21-$} \\
\hline 24 & 0 & 0 & 0 & 0 & 0 & 0 & 0 \\
\hline 25 & 0 & 0 & 0 & 0 & .00030 & .00030 & .00007 \\
\hline$\angle b$ & $U$ & $u$ & 0 & 0 & $.000 \% 0$ & : UUU 10 & ד \\
\hline 27 & 0 & 0 & 0 & 0 & .00010 & .00010 & . ن்ப்ப் \\
\hline 28 & 0 & 0 & 0 & 0 & .00010 & .00010 & .00010 \\
\hline \multicolumn{8}{|l|}{$29-$} \\
\hline 34 & 0 & 0 & 0 & 0 & .0 & $n$ & 0 \\
\hline 35 & .43585 & .00298 & .04427 & .48310 & .89380 & .41070 & .09910 \\
\hline 36 & 0 & 0 & 0 & 0 & .00020 & .00020 & .00005 \\
\hline 37 & 0 & 0 & 0 & 0 & .00150 & .00150 & .00036 \\
\hline 38 & 0 & 0 & $n$ & 0 & .00030 & .00030 & .00007 \\
\hline 39 & 0 & 0 & 0 & 0 & .00180 & $: 00180$ & .00043 \\
\hline 40 & 0 & 0 & 0 & 0 & .00290 & .00290 & .00070 \\
\hline 41 & .00447 & .00005 & .00101 & .00553 & .00640 & .00087 & .00021 \\
\hline 42 & 0 & 0 & 0 & 0 & 0 & 0 & 0 \\
\hline 43 & .00084 & .00001 & .00019 & .00104 & .00090 & . & 0 \\
\hline 44 & 0 & 0 & 0 & 0 & 0 & 0 & 0 \\
\hline 45 & 0 & 0 & 0 & 0 & .00010 & .0001 .0 & .00002 \\
\hline 46 & 0 & 0 & 0 & 0 & 0 & 0 & 0 \\
\hline 47 & .00303 & .00002 & .00068 & .00373 & .02740 & .02367 & .00571 \\
\hline 48 & 0 & 0 & 0 & 0 & .00260 & .00260 & .00063 \\
\hline 49 & .00499 & , 00004 & .00112 & .00614 & .01570 & .00956 & .00231 \\
\hline 50 & .00168 & .01274 & .00029 & .01471 & .04430 & .02959 & .00714 \\
\hline 51 & 0 & 0 & 0 & 0 & $.0 \cap 210$ & .00210 & .00051 \\
\hline 52 & . $\cap \cap 141$ & .00016 & .00032 & .00189 & .00570 & .00381 & .00092 \\
\hline 53 & .00047 & 0 & .00011 & .00058 & .00010 & & 0 \\
\hline 54 & 0 & 0 & 0 & 0 & 0 & 0 & 0 \\
\hline 55 & 0 & 0 & 0 & 0 & 0 & 0 & 0 \\
\hline 56 & .00185 & .00001 & .00042 & .00228 & .02090 & .01862 & .00449 \\
\hline 57 & 0 & 0 & 0 & 0 & .00010 & .00010 & .00002 \\
\hline 58 & 0 & 0 & 0 & 0 & 0 & 0 & 0 \\
\hline 59 & 0 & 0 & 0 & 0 & .00150 & .00150 & .00036 \\
\hline 60 & 0 & 0 & 0 & 0 & .00070 & .00070 & .00017 \\
\hline 62 & 0 & 0 & 0 & 0 & . U2!SU & - UL150 & .00319 \\
\hline 62 & .00330 & .00003 & .00074 & .00407 & .01090 & .00682 & .00165 \\
\hline 63 & 0 & 0 & 0 & $n$ & 0 & 0 & 0 \\
\hline 64 & .01315 & .00010 & .00296 & .01621 & .00010 & & 0 \\
\hline 65 & u & 0 & 0 & 0 & . VUU3ல & .00030 & 7ח \\
\hline 66 & .00311 & .00013 & .00103 & .00493 & .01780 & .01287 & .00377 \\
\hline 67 & .00041 & 0 & 0 & 0 & .00170 & .00170 & 0 \\
\hline 68 & .00022 & 0 & 0 & 0 & .00090 & .00090 & 0 \\
\hline 69 & .00022 & 0 & 0 & 0 & .00090 & .00090 & 0 \\
\hline
\end{tabular}


TABLE 7 (cont'd.)

1967 ELECTRIC OPERATING TRANSACTIONS AND RESIDUALS (1967 Dollars)

AND RESIDUAL P.LLOCATION COEFFICIENTS (1967 $\$ / 10^{6}$ BTU)

\begin{tabular}{|c|c|c|c|c|c|c|c|}
\hline $\begin{array}{l}\text { BNL } \\
\underline{1} 10 \\
\end{array}$ & $\begin{array}{l}\text { Fossil } \\
\text { Electric }\end{array}$ & $\begin{array}{l}\text { Nuclear } \\
\text { LWR } \\
\text { Electric }\end{array}$ & $\begin{array}{l}\text { Hydro- } \\
\text { Electric }\end{array}$ & $\begin{array}{c}\text { Estimate } \\
\text { Total }\end{array}$ & $\begin{array}{c}\text { BEA } \\
\text { Total }\end{array}$ & Residual & $\begin{array}{l}\text { Residual } \\
\text { A! location } \\
\text { Coefficient }\end{array}$ \\
\hline 70 & 0 & 0 & 0 & 0 & 0 & 0 & 0 \\
\hline 71 & 0 & 0 & 0 & 0 & 0 & 0 & 0 \\
\hline 72 & 0 & 0 & 0 & 0 & 0 & 0 & 0 \\
\hline 73 & .01254 & .00010 & .00282 & .01546 & .02740 & .01194 & .00288 \\
\hline 74 & 0 & 0 & 0 & 0 & .00160 & .00160 & .00039 \\
\hline 75 & 0 & 0 & 0 & 0 & 0 & 0 & 0 \\
\hline 76 & 0 & 0 & 0 & 0 & 0 & 0 & 0 \\
\hline 77 & .02660 & .00014 & .00598 & .03272 & .04040 & .00768 & .00185 \\
\hline 78 & 0 & 0 & 0 & 0 & 0 & 0 & 0 \\
\hline 79 & .01268 & .00010 & .00285 & .01563 & .03150 & .01587 & .00383 \\
\hline 80 & 0 & 0 & 0 & 0 & .00110 & .00110 & .00027 \\
\hline 8.1 & .00874 & .00007 & .00197 & .01078 & .00240 & & 0 \\
\hline 82 & .00017 & 0 & .00003 & .00020 & .00200 & .00180 & .00043 \\
\hline 33 & .00027 & 0 & .00006 & .00033 & .00550 & .00517 & .00125 \\
\hline 84 & 0 & 0 & 0 & 0 & 0 & 0 & 0 \\
\hline 85 & 0 & 0 & 0 & 0 & 0 & 0 & 0 \\
\hline 86 & .00013 & .00012 & .00008 & .00033 & .00140 & .00107 & .00026 \\
\hline 87 & 0 & 0 & 0 & 0 & .00010 & .00010 & .00002 \\
\hline 88 & $.00071^{\circ}$ & .00001 & .00016 & .00088 & .00030 & & 0 \\
\hline 89 & .37812 & .00019 & .00003 & .37834 & .45990 & .08156 & .01968 \\
\hline 90 & 0 & 0 & 0 & 0 & 0 & 0 & 0 \\
\hline 91 & .12266 & .00005 & .00001 & .12272 & .12650 & .00378 & .00091 \\
\hline 92 & .04751 & .00002 & 0 & .04753 & .05970 & .01217 & .00294 \\
\hline 93 & .00030 & 0 & 0 & .00030 & .00040 & .00010 & .00002 \\
\hline 94 & .00108 & 0 & 0 & .00108 & .00150 & .00042 & .00010 \\
\hline 95 & 0 & 0 & 0 & 0 & 0 & 0 & 0 \\
\hline 96 & .04782 & .00037 & .01058 & .05877 & .06560 & .00683 & .00165 \\
\hline 97 & 0 & 0 & 0 & 0 & 0 & 0 & 0 \\
\hline 98 & .03124 & .00022 & .00052 & .03198 & .01310 & & 0 \\
\hline 99 & .03325 & .00042 & .00513 & .03880 & .1828 ก & $.1440 n$ & .03475 \\
\hline 100 & .16499 & .00128 & .03710 & .20337 & .12970 & & 0 \\
\hline 101 & .00767 & .00006 & .00102 & .00875 & .06260 & .05385 & .01299 \\
\hline 102 & .00555 & .00004 & .00125 & .00684 & .02000 & .01316 & .00318 \\
\hline 103 & .26740 & .00208 & .06012 & .32960 & .24020 & & 0 \\
\hline 104 & .00625 & .00005 & .00141 & .00771 & .04280 & .03509 & .00847 \\
\hline 105 & 0 & 0 & 0 & 0 & 0 & 0 & 0 \\
\hline 106 & .00911 & .00007 & .00205 & .01123 & .01030 & & 0 \\
\hline 107 & .05924 & .00046 & .01332 & .07302 & .09980 & .02678 & .00646 \\
\hline 108 & .00648 & .00005 & .00146 & .00799 & .00270 & & 0 \\
\hline 109 & .04442 & .00036 & .01012 & .05490 & .07360 & .01870 & .00451 \\
\hline 110 & .01178 & .00015 & .00249 & .01442 & .02410 & .00968 & 0 \\
\hline
\end{tabular}


TABLE 8

1967 FOSSIL ELECTRIC, LIGHT WATER REACTOR ELECTRIC AND HYDROELECTRIC COEFFICIENTS

\begin{tabular}{|c|c|c|c|c|c|c|c|c|c|}
\hline \multirow[t]{2}{*}{$\begin{array}{l}\text { BNL } \\
110\end{array}$} & FOSSIL & $\begin{array}{l}\text { NUCLEAR } \\
\text { LWR }\end{array}$ & $\begin{array}{c}\text { HYDRO- } \\
\text { ELECTRIC }\end{array}$ & & $\begin{array}{r}\text { BNL } \\
110 \\
\end{array}$ & FOSSIL & $\begin{array}{c}\text { NUCLEAR } \\
\text { LWR }\end{array}$ & \multicolumn{2}{|c|}{$\begin{array}{c}\text { HYDRO- } \\
\text { ELECTRIC }\end{array}$} \\
\hline & & & & U /BTU & & & & & 1967 \\
\hline 2 & 2.12470 & 0 & 0 & 1 & 56 & .00504 & .00504 & .00504 & $\$ / 10^{6} \mathrm{BTU}$ \\
\hline 2 & 0 & 0 & 0 & & 57 & .00002 & .00002 & .00002 & \\
\hline 3 & 0 & 0 & 0 & & 58 & 0 & 0 & 0 & \\
\hline 4 & 0 & 0 & 0 & & 59 & .00036 & .00036 & .00036 & \\
\hline 5 & 0 & 0 & 0 & & 60 & .00017 & .00017 & .00017 & \\
\hline 6 & .27886 & 0 & 0 & & 61 & .00519 & .00519 & .00519 & \\
\hline 7 & $.8455 \mathrm{l}$ & 0 & 0 & & 62 & .00263 & .00263 & .00263 & \\
\hline 8 & 0 & 0 & 0 & & 63 & 0 & 0 & 0 & \\
\hline 9 & .08800 & 0 & 0 & & 64 & .00391 & .00391 & .00391 & \\
\hline 10 & 0 & .08802 & 0 & & 65 & .00007 & .00007 & .00007 & \\
\hline 11 & 0 & 0 & 0 & & 66 & .00423 & .00804 & .00447 & \\
\hline 12 & 0 & 0 & .08731 & & 67 & .00041 & .00041 & .00041 & \\
\hline 13 & 0 & 0 & 0 & & 68 & .00022 & .00022 & .00022 & \\
\hline 14 & .00005 & .00005 & 5 חמחמם . & & 69 & . $n \cap n 22$ & .00022 & .000022 & \\
\hline 15 & .00089 & .00089 & .00089 & & 70 & 0 & 0 & 0 & \\
\hline 1.6 & 0 & 0 & 0 & & 71 & 0 & $0^{\circ}$ & 0 & \\
\hline 17 & .00035 & .00035 & .00035 & . & 72 & 0 & 0 & 0 & \\
\hline 18 & .00579 & .00579 & .00579 & & 73 & .00661 & .00661 & .00661 & \\
\hline 19 & .00094 & .00094 & .00094 & & 74 & .00039 &, 00039 & .00039 & \\
\hline 20 & .00277 & -00277 & .00277 & & 75 & 0 & 0 & 0 & \\
\hline 21 & 0 & 0 & $01967 \$$ & $10^{6} \mathrm{BTU}$ & 76 & 0 & 0 & 0 & \\
\hline 22 & 0 & 0 & 0 & & 77 & .00976 & .00721 & .00976 & \\
\hline 23 & 0 & 0 & 0 & & 78 & 0 & 0 & 0 & \\
\hline 24 & 0 & 0 & 0 & & 79 & .00760 & .00760 & .00760 & \\
\hline 25 & 00007 & $.0000 ?$ & .00007 & & 80 & .00027 & .00027 & .00027 & \\
\hline 26 & .00017 & .00017 & .00017 & & 81 & .00260 & .00260 & .00260 & \\
\hline 27 & .00002 & .00002 & .00002 & & 82 & .00048 & .00048 & .00047 & \\
\hline 28 & .00010 & .00010 & .00010 & & 83 & .00133 & .00133 & .00133 & \\
\hline 29 & 0 & 0 & 0 & & 84 & 0 & 0 & 0 & \\
\hline 30 & 0 & 0 & 0 & & 85 & 0 & 0 & 0 & \\
\hline 32 & 0 & 0 & 0 & & 86 & .00030 & .00470 & .00037 & \\
\hline 32. & 0 & 0 & 0 & & 87 & .00002 & .00002 & .00002 & \\
\hline 33 & 0 & 0 & 0 & & 88 & .00021 & .00021 & . บบ021 & \\
\hline 34 & 0 & 0 & 0 & & 89 & .13214 & .02682 & .01972 & \\
\hline 36 & .22873 & .21337 & .15766 & & 90 & 0 & 0 & 0 & \\
\hline 36 & .00005 & .00005 & .00005 & & 91 & .03739 & .00295 & .00092 & \\
\hline 37 & .00036 & .00035 & .00036 & & 92 & .01707 & .00376 & .00294 & \\
\hline 38 & .00007 & .00007 & .00007 & & 93 & .00011 & .00012 & .00002 & \\
\hline 39 & .00043 & .00043 & .00043 & & 94 & .00042 & .00020 & .00010 & \\
\hline 40 & .00070 & .00070 & .00070 & & 95 & 0 & 0 & 0 & \\
\hline 41 & .00154 & .00229 & .00154 & & 96 & .01507 & .01503 & $: 01561$ & \\
\hline 42 & 0 & 0 & 0 & & 97 & 0 & 0 & 0 & \\
\hline 43. & .00025 & .00025 & .00025 & & 98 & .00929 & .00837 & .00069 & \\
\hline 44 & 0 & 0 & 0 & & 99 & .04464 & .05034 & .04153 & \\
\hline 45 & .00002 & .00002 & . ט0̈0்Z & & 100 & 04707 & .04207 & .04907 & \\
\hline 46 & 0 & 0 & 0 & & 101 & .01527 & .01527 & .01434 & \\
\hline 47 & .00661 & .00661 & .00661 & & 102 & .00183 & .00483 & .00483 & \\
\hline 48 & .00063 & .00063 & .00063 & & 103 & .07953 & .07953 & .07953 & \\
\hline 49 & .00379 & .00379 & .00379 & & $104^{\circ}$ & .01033 & .01033 & .01033 & \\
\hline 50 & .00764 & .49488 & .00752 & & 105 & 0 & 0 & 0 & \\
\hline 51 & .00051 & .00051 & .00031 & & 106 & .00271 & .00271 & 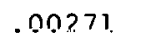 & \\
\hline 52 & .00134 & .00722 & .00134 & & 107 & .02408 & .02408 & .02408 & \\
\hline 53. & .00014 & .00014 & .00014 & & 108 & .00193 & .00193 & .00193 & \\
\hline 54 & 0 & 0 & 0 & $\sqrt{1}$ & 109 & .01772 & .01830 & .01789 & \\
\hline 55 & 0 & 0 & 0 & & 110 & .00350 & .00575 & .00329 & $V$ \\
\hline
\end{tabular}


MITRE report [6] included only the processing of the coal to gas; so all. coal gas produced goes to the pipeline gas sector for distribution in the I-0 model.

4.1 Energy Supply Inputs

The only input to this sector for processing of coal to gas from other energy supply sectors is the coal. Any other energy neers for the conversion process are produced from the coal and are incluier as part of the process technology. The report gives a coefficient for BTUs of coal input per BTU of gas output of 1.620743 .

\subsection{Energy Product Inputs}

The only energy input other than coal shown in the MITRE report is refined oil. The total value of this input is given as $\$ 48,880$. The total energy content is given as $1.75 \times 10^{10}$ BTUs. Although $\$ 13,880$ is indicated as being for "power generation", the text of the report states that this is "omitted fuel pirchases". So this input probably represents lubricants used in the coal-fired power plant. The remainder is listed as being for "supplies" and probably is nostly for vehicle fuel and oil although some might be for other energy products such as water heat or space heat. Applying the dollar fractions to the total refined oil BTU content, the two parts consist of $.4969 \times 10^{10}$ BTUs and $1.253 \times 10^{10}$ BTUs. Normalizing these with respect to the annual BTU coal gas outpiat of the plant gives coefficients of $.30255 \times 10^{-4}$ BTU/BTU for chemical feedstocks (which includes lubricants) and $.83346 \times 10^{-4}$ BTU/BTU for other uses. The latter coefficient is ignored in view of the following.

Subjective evaluation of the coal gasification process makes it appear more similar to petroleum refining than to any of the other energy supply sectors examined by Bullard and Knecht [5] in terms of its requirements for energy products such as water heat or motive power. Examination of the notive power inpit coefficients for petroleum refining indicate the same general degree of fuel usaye as indicated in the MITRE report. For lack of more complete data we will simply adopt the assumption that energy product use in the coal gasification sector is identical to that ceriver for refinea petroleum except for chemical feerstocks and process heat requirements. The process heat requirements here are primarily included as part of the process and already counted in the coal input. Process heat inpilt thus will be zoro. For chemical feedstocks we use the coefficient derived above from the MITRE data.

4.3 Non-Energy Inpiats

Non-energy inputs are aggregated directly from MITRE coefficients, [6, vol, 1, pp. 62-65]. 
TABLE 9

1985 HIGH BTU COAL GASIFICATION COEFFICIENTS

(METHANE FROM COAL)

\begin{tabular}{|c|c|c|c|c|c|c|}
\hline $\begin{array}{l}\text { BNL } \\
110 \\
\end{array}$ & $\begin{array}{c}\text { A MATRIX } \\
\text { COEFFICIENTS }\end{array}$ & & $\begin{array}{l}\text { BNL } \\
110 \\
\end{array}$ & $\begin{array}{r}\text { A MAT } \\
\text { COEFFIC } \\
\end{array}$ & $\begin{array}{l}\text { IX } \\
\text { ENTS } \\
\end{array}$ & \\
\hline 1 & 1.620743 & BTU/BTU & 56 & .00015 & $1967 \$ / 10^{6}$ & BTU \\
\hline 2 & 0 & 1 & 57 & 0 & 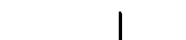 & \\
\hline 3 & 0 & & 58 & 0 & & \\
\hline 4 & 0 & & 59 & .00002 & & \\
\hline 5 & 0 & & 60 & .00008 & & \\
\hline 6 & 0 & & 61 & .00016 & & \\
\hline 7 & 0 & & 62 & .00045 & & \\
\hline 8 & 0 & & 63 & .00024 & & \\
\hline 9 & 0 & & 64 & 0 & & \\
\hline 10 & 0 & & 65 & 0 & & \\
\hline 11 & 0 & & 86 & .00011 & & \\
\hline 12 & 0 & & 67 & 0 & . & \\
\hline 23. & 0 & & 68 & 0 & & \\
\hline 14 & . & & 69 & .00043 & & \\
\hline 15 & .00001 & & 70 & .00004 & & \\
\hline 16 & 0 & & 71 & .00009 & & \\
\hline 17 & 0 & & 12 & . vن்ப் $2 \dot{0}$ & & \\
\hline 18 & .00011 & & 73 & .00016 & & \\
\hline 19 & .00014 & $k$ & 71 & 0 & & \\
\hline 20 & .00219 & $V$ & 75 & 0 & & \\
\hline$\frac{21}{21}$ & 1967 & $\$ / 10^{6} \mathrm{BTU}$ & 76 & 0 & & \\
\hline 22 & 0 & 1 & 77 & .00003 & & \\
\hline 23 & 0 & & 78 & 0 & & \\
\hline 24 & 0 & & 79 & .00003 & & \\
\hline 25 & 0 & & 80 & 0 & & \\
\hline 26 & 0 & & 81 & 0 & & \\
\hline 27 & .01744 & & 82 & 0 & & \\
\hline 28 & 0 & & 83 & .00002 & & \\
\hline 29 & 0 & & 34 & 0 & & \\
\hline 30 & 0 & & 35 & 0 & & \\
\hline 31 & $n$ & & 86 & .00002 & & \\
\hline $3 \%$ & $\dot{v}$ & & 87 & .00001 & & \\
\hline 33 & 0 & & 88 & .00002 & & \\
\hline 34 & 0 & & 89 & .00174 & & \\
\hline 35 & .00910 & & 90 & 0 & & \\
\hline 36 & .00001 & & 91 & .00100 & & \\
\hline 37 & 0 & & 92 & .00174 & & \\
\hline 38 & 0 & & 93 & .00005 & & \\
\hline 39 & .00011 & & 94 & .00045 & & \\
\hline 40 & .00001 & & 95 & 0 & & \\
\hline 41. & .00002 & & 96 & .00092 & & \\
\hline 42 & .00002 & & 97 & 0 & & \\
\hline 43 & .00004 & & 98 & .01324 & & \\
\hline 44 & 0 & & 99 & .00085 & & \\
\hline 45 & 0 & & 100 & .02313 & & \\
\hline 46 & 0 & & 101 & .00387 & & \\
\hline 47 & .00096 & & 102 & .00017 & & \\
\hline 48 & .00018 & & 103 & .00557 & & \\
\hline 49 & .00054 & & 104 & .00018 & & \\
\hline 50 & .00549 & & 105 & 0 & & \\
\hline 51 & 0 & & 106 & .00011 & & \\
\hline 52 & .00053 & & 107 & U & & \\
\hline 53 & .00012 & & 108 & 0 & & \\
\hline 54 & 0 & & 109 & .00147 & & \\
\hline 55 & 0 & V & 110 & .00018 & V & \\
\hline
\end{tabular}




\section{SOLVENT-REFINED COAL}

Solvent-refined coal is an ashless, desulfurized fuel from coal intended for use primarily as a boiler fuel for electricity generation and as a feedstock for petrochemical industries. At room temperature it is a solid while under moderate heat $\left(400^{\circ} \mathrm{F}\right.$ ) it becomes a liquid. Thus it can substitute for both regular coal and residual oil as a boiler fuel. In the 110 sector I-O model it can only be used as a boiler fuel at present, not as a chemical feedstock.

5.1 Energy Supply Inputs

As was the case for coal gasification, the only energy supply input to this technology is the coal consumed and converted in the process. The coefficient is 1.697 BTUs of coal input per BTU of solvent refined coal output.

5.2 Energy Product Inputs

The only energy product requirement explicitly indicated in the MITRE report was $1.04 \times 1014$ BTUs of natural gas for process heat. Assuming a burner efficiency of $64 \%$ (as used in reference [5]), this amounts to $.6656 \times 10^{14}$ BTUs of process heat. Normalizing by the total output of solvent refined coal, and then adjusting the process heat coefficient by .90 to project to 1985 , we get a coefficient of $.058068 \mathrm{BTU} / \mathrm{BTU}$ for process heat requirements.

The remaining energy product coefficients must be approximated by some known set as was done previously. Again, of all previously examined energy supply technologies, petroleum refining seems to be the most similar. So we will assume energy product coefficients for solvent-refined coal identical to those for refined petroleum for all energy products except process heat and chemical feedstocks. For feedstocks, we will use the coefficient from the coal gasification technology.

5.3 Non-Energy Inputs

Since the coefficients for inputs from the non-energy sectors are available directly from the MITRE data in $10^{6} \$ / 10^{15}$ RTU 6 , Vol. I, pi. 59-60] it was only necessary to multiply them by $10^{3}$ to adjust the units to $\$ / 10^{6} \mathrm{BTU}$ and then aggregate and re-order them to correspond to our 90 non-energy sectors. The coefficients are listed in Table 10.

\section{SHALE OIL}

The technology represented here includes mining of the shale and retorting it to a high-grade, low sulfur crude oil. This processing is assumed to be done at the mine-mouth (but not in situ), and the crude oil is shipped to refineries for further refining. 
TABLE 10

1985 SOLVENT REFINED COAL COEFFICIENTS

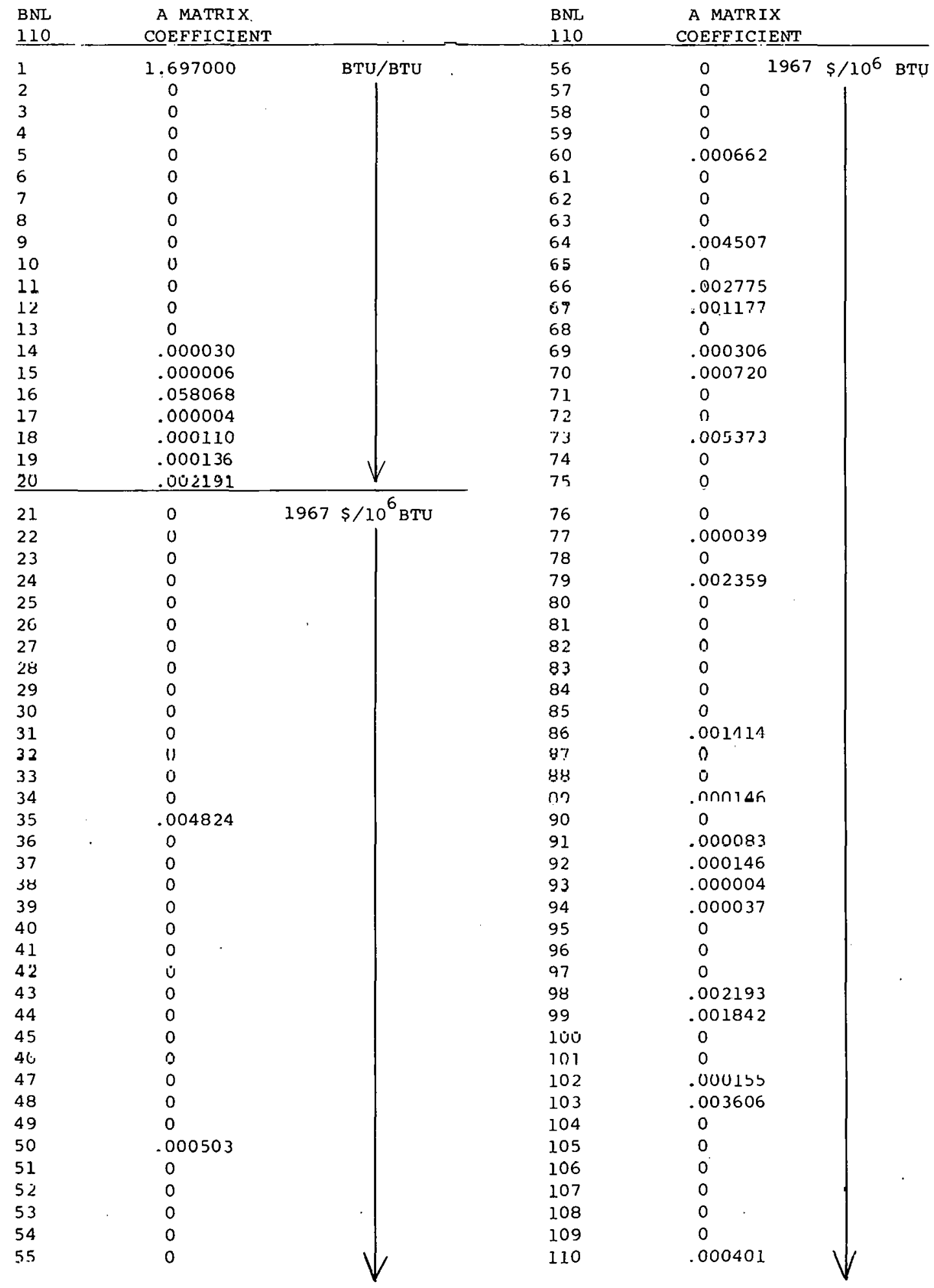




\subsection{Energy Supply Inputs}

Since this technology represents resource extraction and not conversion there is no supply entry similar to that found in the previous two technologies. However, there is indicated the use of $6.78 \times 10^{11}$ BTUs of natural gas for "methane reforming" in the processing of the shale to a crude oil. This is a feedstock use of the methane but evidently a non-substitutable one. As such it should enter as a supply coefficient rather than as an energy product since the latter formulation would enable the model to substitute feedstocks other than methane. The coefficient indicated by the MITRE data is .006405 and will be an input from the natural gas sector to the shale oil sector. At the present time this use of natural gas is not incorporated in the 110 sector model.

6.2 Energy Product Inputs

The only energy product input given in the MITRE report is a small amount of refined petroleum for vehicle fuel. This technology seems to have some of the characteristics of coal mining or stone quarrying, or crude oil extraction, and of oil refining. As a first approximation we will assume that the energy product requirements for mining and retorting a ton of shale are equal to the requirements for mining a ton of coal. This enables us to calculate the energy product coefficients for the shale oil sector by multiplying the energy product coefficients of the coal sector by the ratio of the BTU content of a ton of shale [7] to the BTU content of a ton of coal. (Ref. [7] gives shale yield of $35 \mathrm{gal}$. Of crude oil per ton of shale; at $5,800,000 \mathrm{BTU} / \mathrm{bbl}$. of crude and $42 \mathrm{gal} . / \mathrm{bbl}$. this converts to $4,833,333 \mathrm{BTU} / \mathrm{ton}$ of shale versus $26,200,000 \mathrm{BTU} / \mathrm{ton}$ of coal.)

6.3 Non-Energy Inputs

As with solvent-refined coal, the shale oil coefficients are directly available from the MITRE data [6, Vol. I, pp. 56-57] and need only be adjusted for unit, aggregation and ordering differences. The coefficients are printed in Table 11.

\section{HIGH TEMPERATURE GAS -COOLED REACTOR (HTGR) ELECTRIC}

The technology represented here includes the generation of electricity by a high temperature gas-cooled nuclear reactor (HTGR) as well as the transmission and distribution of the electricity generated and the administration of the entire range of activities. These nnn-generating, or overhead, aclivities are included so that the sector will parallel the BEA sector for electric utilities and our previous disaggregation of that sector in section 3 . The MITRE data includes only the inputs required for 
TABLE 11

1985 SHALE OIL COEFFICIENTS

\begin{tabular}{|c|c|c|c|c|c|c|}
\hline $\begin{array}{l}\text { BNL } \\
110 \\
\end{array}$ & $\begin{array}{c}\text { A MATRIX } \\
\text { COEFFICIENT }\end{array}$ & & $\begin{array}{l}\text { BNL } \\
110 \\
\end{array}$ & $\begin{array}{r}\text { A MATRIX } \\
\text { COEFFICIE }\end{array}$ & & \\
\hline 1 & 0 & $\mathrm{BTU} / \mathrm{BTU}$ & 56 & .002057 & 1967 & $\$ / 10^{6} \mathrm{BTU}$ \\
\hline 2 & 0 & 1 & 57 & 0 & & \\
\hline 3 & 0 & & 58 & 0 & & \\
\hline 4 & 0 & & 59 & 0 & & \\
\hline 5 & 0 & & 60 & 0 & & \\
\hline 6 & 0 & & 61 & 0 & & \\
\hline 7 & 0 & & 62 & 0 & & \\
\hline 8 & 0 & & 63 & 0 & & \\
\hline 9 & 0 & & 64 & .000872 & & \\
\hline 10 & 0 & & 65 & .001104 & & \\
\hline 11 & 0 & & $\sin$ & .000590 & & \\
\hline 12 & 0 & & 07 & .000090 & & \\
\hline 13 & 0 & & 68 & 0 & & \\
\hline 14 & .000001 & & 69 & .006994 & & \\
\hline 15 & חnחกו & & 70 & .000854 & & \\
\hline 16 & .000097 & & 71 & 0 & & \\
\hline 17 & .000001 & & 72 & 0 & & \\
\hline 18 & 0 & & 73 & .002496 & & \\
\hline 19 & 0 & k & 74 & 0 & & \\
\hline 20 & .000025 & $V$ & 75 & 0 & & \\
\hline 21 & 0 & $1967 \$ / 10^{6} \mathrm{BTU}$ & 76 & 0 & & \\
\hline 22 & 0 & 1 & 77 & .002246 & & \\
\hline 23 & 0 & & 78 & 0 & & \\
\hline 24 & 0 & & 79 & 0 & & \\
\hline 25 & 0 & & 80 & .000821 & & \\
\hline 26 & 0 & & 81 & 0 & & \\
\hline 27 & 0 & & 82 & 0 & & \\
\hline 20 & 0 & & 8.3 & .000618 & & \\
\hline 29 & 0 & & 84 & 0 & & \\
\hline 30 & 0 & & 85 & 0 & & \\
\hline 31 & 0 & & 86 & .000619 & & \\
\hline 32 & 0 & & 87 & 0 & & \\
\hline 33 & 0 & & 88 & 0 & & \\
\hline 34 & 0 & & 89 & $.00044 J$ & & \\
\hline 35 & .008060 & & 90 & .000253 & & \\
\hline 36 & 0 & & 91 & .000443 & & \\
\hline 37 & 0 & & 92 & 0 & & \\
\hline 38 & 0 & & 93 & .000013 & & \\
\hline 39 & 0 & & 94 & .000114 & & \\
\hline 40 & 0 & & 95 & 0 & & \\
\hline 41 & 0 & . & 96 & .001189 & & \\
\hline $4 \%$ & $\dot{u}$ & & 37 & 0 & & \\
\hline 43 & 0 & & 98 & .001878 & & \\
\hline 44 & 0 & & 99 & .003786 & & \\
\hline 45 & 0 & & 100 & .025971 & & \\
\hline 16 & 0 & & 101 & .022496 & & \\
\hline 47 & 0 & & 102 & .000149 & & \\
\hline 48 & 0 & & 103 & .007763 & & \\
\hline 49 & .000154 & & 104 & .002639 & & \\
\hline 50 & .0 .30 .320 & & 105 & 0 & & \\
\hline 51 & 0 & & 106 & .001139 & & \\
\hline 52 & 0 & & 107 & 0 & & \\
\hline 53 & 0 & & 108 & 0 & & \\
\hline 54 & 0 & $\sqrt{ }$ & 109 & .001713 & & \\
\hline 55 & 0 & & 110 & .000173 & & V \\
\hline
\end{tabular}


generation and none of the overhead requirements. Thus in addition to the data restructuring done for the previous two technologies, we also must calculate and add on a vector of coefficients for inputs to the overhead activities, and for residual

BEA sectoral transactions.

7.1 Electric Overhead and BEA Residual Allocation

In section 3 of this report, using the MITRE data for electricity generation by a Light water Reactor (LWR) and BEA and Istvan data for electric utilities, a vector of coefficients was obtained for the IWR which included transmission, distribution and administration requirements as well as the generation requirements. Assuming that all electric generation technologies have the same requirements for transmission, distribution and administration and that all of the generation process vectors developed by MITRE are consistent in their treatment of these overhead requirements, then we can simply take the electric overhead coefficients presented in Table 6 and the residual allocation coefficients presented in Table 7 and add them to the MITRE coefficients.

7.2 Energy Supply Inputs

Since the MITRE data did not explicitly derive energy supply or energy product data, the vector just calculated has no energy supply or product coefficients.

The HTGR will have no energy supply inputs for conversion because the nuclear fuel used in the conversion to electricity is a product of the chemical sector (sector 50) and not of an energy supply sector. However, transmission and distribution of electricity is assumed to consume $9 \%$ of all electricity generated. so there will be a selfuse coefficient of .09 .

7.3 Energy Product Inputs

Again, the MITRE data indicates only lubricants and vehicle fuel. Here we have a very similar technology, in terms of its energy product requirements, to draw on. We can assume that the energy product inputs to the HTGR are identical to those derived for the LWR in 'lable 8.

7.4 Non-Energy Inputs

The vector for the generating requirements of the HTGR obtained from the MITRE data must be modified as with the previous technologies: adjusting the units, aggregating, and reordering to our 90 sectors. Then the electric overhead coefficients and BEA residual alloration cocfficients must be added. The final vector for the HTGR is given in Table 12 .

\section{COAL COMBINED CYCLE ELECTRIC}

This is actually the combination of two processes into a 
TABLE 12

$1985^{\circ}$ HIGH TEMPERATURE GAS-COOLED REACTOR COEFFICIENTS

\begin{tabular}{|c|c|c|c|c|c|}
\hline $\begin{array}{l}\text { BNL } \\
110 \\
\end{array}$ & $\begin{array}{l}\text { A MATRIX } \\
\text { COEFFICIENTS }\end{array}$ & & $\begin{array}{l}\text { BNL } \\
110 \\
\end{array}$ & $\begin{array}{l}\text { A MATRIX } \\
\text { COEFFICIENTS }\end{array}$ & \\
\hline 1 & 0 & $\mathrm{BTU} / \mathrm{BTU}$ & 56 & $.00504 \quad 1967$ & $\$ / 10^{6} \mathrm{BTU}$ \\
\hline 2 & 0 & & 57 & .00002 & \\
\hline 3 & 0 & & 58 & 0 & \\
\hline 4 & 0 & & 59 & .00036 & \\
\hline 5 & 0 & & 60 & .00017 & . \\
\hline 6 & 0 & & 61 & .00519 & \\
\hline 7 & 0 & & 62 & .00263 & \\
\hline 8 & 0 & & 63 & 0 & \\
\hline 9 & 0 & & 64 & .00488 & \\
\hline 10 & 0 & & 65 & .00007 & \\
\hline 1.1 & .090000 & & 66 & .00913 & \\
\hline 12 & 0 & & 67 & . onnal & \\
\hline 13 & 0 & & 68 & 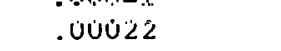 & \\
\hline 1.4 & .00005 & & 69 & .00022 & \\
\hline 13 & .00889 & & 70 & 0 & \\
\hline 16 & & & 71 & (1) & \\
\hline 1.7 & .00035 & & 72 & .01180 & \\
\hline 18 & .00578 & & 73 & .00734 & \\
\hline 19 & .00094 & & 74 & .00039 & \\
\hline 20 & .00217 & $y$ & 75 & 0 & \\
\hline 21 & 0 & $1967 \$ / 10^{6} \mathrm{BTU}$ & 76 & 0 & \\
\hline 22 & 0 & - & 77 & .00839 & \\
\hline 23 & 0 & & 78 & 0 & \\
\hline 24 & 0 & & 79 & .00760 & \\
\hline 25 & .00007 & & 80 & .00027 & \\
\hline 26 & .00017 & & 81 & .00410 & \\
\hline 27 & .00002 & & 82 & .00043 & \\
\hline 28 & .00010 & & 83 & .00125 & \\
\hline 29 & 0 & & 84 & 0 & \\
\hline 30 & 0 & & 85 & 0 & \\
\hline 31 & 0 & & 86 & .00573 & \\
\hline 32 & $n$ & & 87 & .00002 & \\
\hline 33 & 0 & & 88 & .00021 & \\
\hline 34 & 0 & · & 89 & ก?.8. 3 & \\
\hline 35 & .12700 & & 90 & 0 & \\
\hline 36 & .00005 & & 91 & .003332 & \\
\hline 37 & .00036 & & 92 & .00391 & \\
\hline 38 & .00007 & & 93 & .00015 & \\
\hline 39 & .00043 & & 94 & .00022 & \\
\hline 40 & .00070 & & 95 & 0 & \\
\hline 41 & .00102 & & 96 & .01611 & \\
\hline 42 & 0 & & 97 & 0 & \\
\hline 43 & .00025 & & 98 & .00937 & \\
\hline$\Delta 4$ & 0 & & 99 & .05340 & \\
\hline 45 & .00002 & & 100 & .05239 & \\
\hline 40 & u & & 1.01 & .01538 & \\
\hline 47 & .00661 & & 102 & .04532 & \\
\hline 48 & .00063 & & 103 & .08337 & \\
\hline 49 & .00411 & & 104 & .01039 & \\
\hline 50 & .56070 & & 105 & 0 & \\
\hline 51 & .00051 & & 106 & .00302 & \\
\hline 52 & .00092 & & 107 & .02413 & \\
\hline 53 & 0 & & 108 & .00193 & \\
\hline 54 & 0 & $1 /$ & 109 & .01857 & \\
\hline 55 & 0 & & 110 & .00732 & $V$ \\
\hline
\end{tabular}


single I-0 sector. The first process is low BTU gasification of coal. The second process uses this gas in a second generation COGAS combined cycle generating plant. The MITRE report gives vectors for each of these processes.

To combine these two processes into a single technology, coal Combined Cycle Electric (CCC), we first multiply the MITRE coefficients for input requirements to the low BTU gasification process by the BTUs of gas required by the COGAS plant to get the dollar (for non-energy sectors) and BTU (for energy sectors) inputs required by the gasification process. Multiplying the MITRE coefficients for inputs to the COGAS plant by the BTUs of electricity generated gives the inputs required by the COGAS generating process. The sum of these two gives the total inputs required by the combined technology. To get coefficients for this combined technology we divide these inputs by the BTUs of electricity generated. Using values for annual production taken from the MITRE report the above operation can be written for each sector, i, as

$\operatorname{CCC}(I)=\left(\right.$ LOWGAS $\left.(I) * 3.83897 \times 10^{7}+\operatorname{COGAS}(I) * 2.092238 \times 10^{7}\right) / 2.092238 \times 10^{7}$

This gives us a vector of coefficients for the combined processes at the same level of aggregation and in the same ordering as the MITRE data.

8.I. Energy Supply Inputs

The operation just described results in a coefficient of 2.10972 for BTUs of coal input per BTU of electricity output. There is also some electricity consumed by the coal gasification process. We assumed this will be consumed from the output of the CCC plant and is a non-substitutable selfuse of electricity. The coefficient for this consumption derived from the MITRE data is .0583749. To this must be added the transmission and distribution loss coefficient of .09 to get the total selfuse coefEicient for CLC of . 148375 .

8.2 Energy Product Inputs

Again, the MITRE data is sketchy and incomplete so we will simply assume that energy product requirements are the same as for regular fossil electric generation as presented in Table 8. 8.3 Non-Energy Inputs

After aggregating and reordering the vector derived from the MITRE data, we must add on the overhead vector derived previously. Since the output of the combined processes is generated electricity, we must add the electric overhead coefficients (Table 6) and the BEA residual allocation coefficients (Table 7) so that this electric generation technology will parallel the other generating sectors. The final vector is given in Table 13. 
TABLE 13

1985 COAL COMBINED CYCLE ELECTRIC COEFFICIENTS

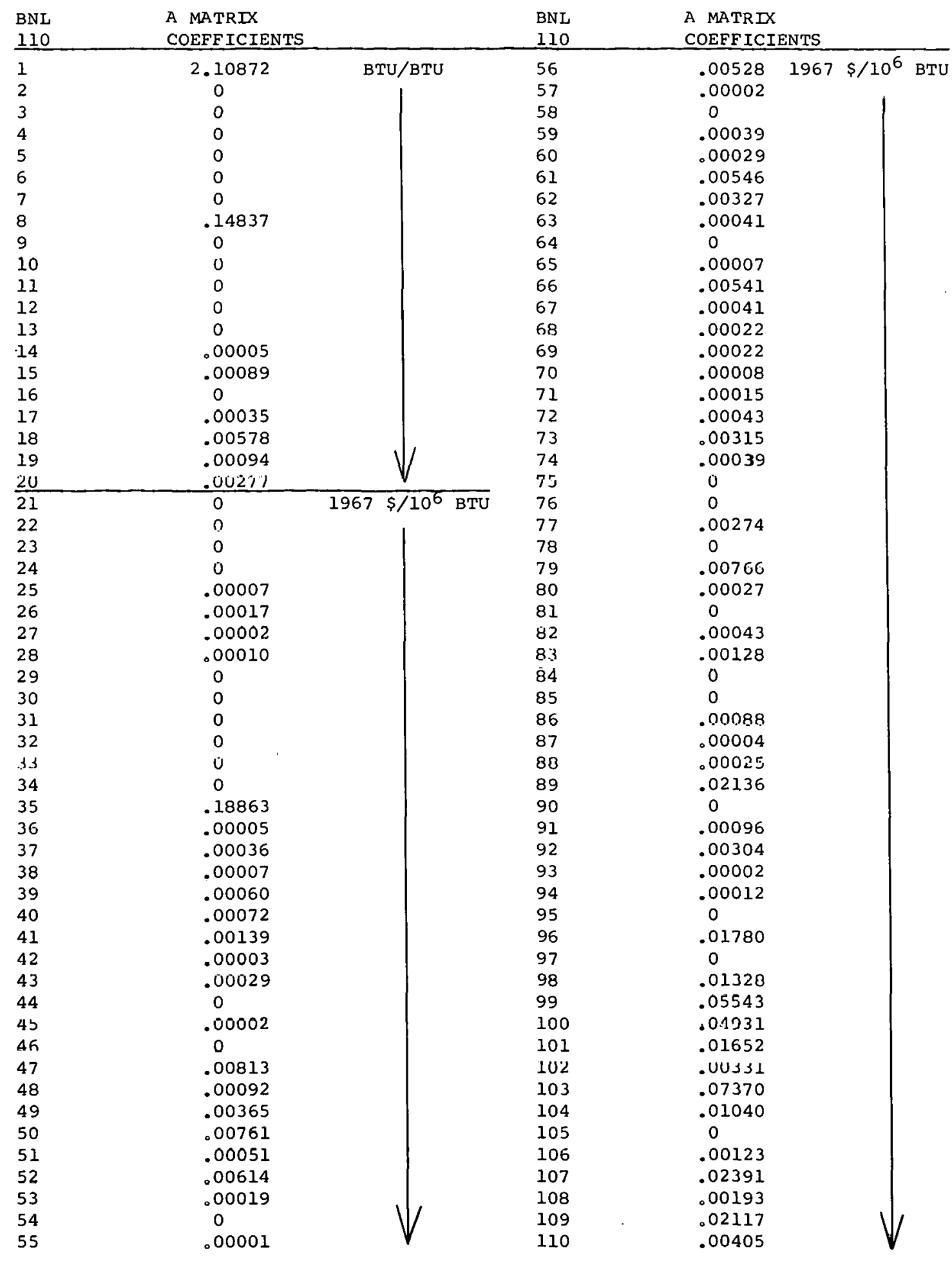




\section{REFERENCES}

[1] Bullard, C. W., "An Input-Output Model for Energy Demand Analysis," Document No. 146, Center for Advanced Computation, University of Illinois, Urbana, Illinois, January 1975.

[2] Behling, D. J., Marcuse,.W., Swift, M., and Tessmer, R., "A Two-level Iterative Model for Estimating Inter-Fuel Substitution Effects, BNL 19863," Paper presented at 1985 Summer Computer Simulation Conference, San Francisco, July 1975

[3] United States Department of Commerce, Bureau of Economic Analysis, "Survey of Current Business," Vol. 54, No. 2, February 1974, pp. 34-37.

[4] Swift, M., "Technical Coefficients for Inputs to Energy Supply Sectors from Non-Energy Sectors," Technical Memorandum No. 46, Center for Advanced Computation, University of Illinois, Urbana, Illinois, January 1975.

[5] Bullard, C. W., and Knecht, R., "End Uses of Energy in the U. S. Economy 1967 ," Document No 145, Center for Advanced Computation, University of Illinois, Urbana, Illinois, January 1975.

[6] Just, James, Borko, B., Parker, W., and Ashmore, A., "New Energy Technology Coefficients and Dynamic Energy Models," Energy Research and Development Administration, ERDA-3, January 1975.

[7] Clark, C. E., and Varisco, D. C., "Net Energy and Oil Shale," presented at NSF (RANN) Workshop on Net Energy, University of California, San Diego, La Jolla, California, January 21,1975 .

[8] Edison Electric Institute, "Statistical. Yearbook of the Electric Utility Industry for 1971," New York, 1972.

[9] Bowman, Charles, U. S. Dept. of Labor, Bureau of Labor Statistics, privatc communication, June 1.974.

[10] Swift, M. A., "Technical Coefficients for Inputs to New Energy Technologies, "Technical Memorandum No. 49, Center 
for Advanced Computation, University of Illinois, Urbana, Illinois, April 1975.

[11] Department of Commerce, "Input-Output Structure of the U. S. Economy: $1963, "$ Vols: 1-3, 1969.

[12] Simpson, David, "Energy Use in U. S. Economy, 1967," Technical Memorandum No. 39, Center for Advanced Computation, University of Illinois, Urbana, Illinois, November 1974 .

[13] Istvan, Rudyard, "1980 Inputs for Private Electric Utilities," Harvard Economia Rcooaroh Projoat, Cambridgo, Macoaohuoottc, August 1971 .

[14] Department of Commerce, "Input-Output structure of the U. S. Economy: 1967," Vols. 1-3, 1974.

[15] U. S. Department of Labor, Bureau of Labor Statistics. Their 134-order 1980 and 1985 Input-Output Forecasts, and 134order list of deflators for the years 1958-1971. Unpublished, data tapes available from BLS, Washington, D.C.

[16] Knecht, Ronald L., "Refinements on the Energy End Uses Input-Output Model," Technical Memorandum No. 59, Center for Advanced Computation, University of Illinois, Urbana, Illinois, October 1975.

[17] U. S. Energy Research and Development Report, ERDA-48, "A National plan for Energy Research, Development and Demonstration: Creating Energy Choices for the Future," Washington D. C., June 1975.

[18] Beller, M. (ed.), Sourcebook for Energy Assessment, Brookhaven National Laboratory Report, BNL 50483 , November 1975 . 


\section{APPENDIX: 1963-1967 INFLATORS}

This appendix describes the construction of a vector of inflators for converting 1963 dollar transactions into equivalent 1967 dollar transactions for each sector. The data used comes from unpublished reports of the Bureau of Labor Statistics and neither they nor we guarantee its accuracy. (9) The data consists of the 1967 total output for each of 134 sectors expressed in 1967 dollars, $\mathrm{X}_{\mathrm{k}}^{67,67}$; 1967 total output for these sectors expressed in 1963 dollars, $\mathrm{x}_{\mathrm{k}_{63}, 63}, 63$ and an inflator coefficient for each of these sectors, $\mu_{\mathrm{k}}, 67$.

Table 1 in the text presents the correspondence between the BLS sectors and our 110 sector model: column two gives the sector name; column one lists the 110 order sector number; column four lists the corresponding BEA sector number; and column seven gives the associated BLS sector or sectors.

The mapping from the 134 BLS sectors to our 110 sectors is sometimes one-to-many and frequently many-to-one. Letting the subscript $k$ denote the 134 BLS sectors and the subscript $i$ denote our 110 sectors we can simply write

$$
\mu_{i}^{53,67}=\mu_{k}^{63,67}
$$

when there is a one-to-one mapping from $k$ to $i$. When the mapping is one-to-many, as in the case of $k=42$ which corresponds to $i=6,54$, and 55 we assume that the inflator value for a sector is valid for all subsectors. This implies

$$
\mu_{i}^{63,67}=\mu_{k}^{63,67}
$$

for every $i$ associated with $k$. When the mapping is many-to-one and there are many different inflation rates which must be combined to yield a single coefficient, we must return to the equation relating the coefficients to total outputs:

$$
\mu_{\mathrm{k}}^{63,67}=\mathrm{x}_{\mathrm{k}}^{67,67} / \mathrm{x}_{\mathrm{k}}^{67,63}
$$

For the case where there are many sectors $\mathrm{k}$ associated with a single sector $i$, we then get

$$
\mu_{i}^{63,67}=\sum_{k \rightarrow i} x_{k}^{67,67} / \sum_{k \rightarrow i} x_{k}^{67,63}
$$

There is one special case where one $k$ sector and part of another are mapped into one sector $i$, while the remainder of the second $\mathrm{k}$ sector is mapped into a different $i$. This occurs with sectors $k=27$ and $k=28$. All of 27 and $91.29 \%$ of the 1967 total 
output in 1967 of sector 28 are associated with sector $i=43$. The remaining $8.71 \%$ of the total output of 28 is associated with $i=44$ In a parallel to the above equation we can see that

$$
\mu_{43}^{63,67}=\left(x_{27}^{67,67}+(.9129) x_{28}^{67,67}\right) /\left(x_{27}^{67,63}+(.9129) x_{28}^{67,63}\right)
$$

and

$$
\mu_{44}^{63,67}=(.0871) x_{28}^{67,67} /(.0871) x_{28}^{67,63}=\mu_{28}^{63,67}
$$

